\title{
The fate of lake ice in the North American Arctic
}

\author{
L. C. Brown and C. R. Duguay \\ Department of Geography and Environmental Management and Interdisciplinary Centre for Climate Change (IC ${ }^{3}$ ), University \\ of Waterloo, Waterloo, Ontario, N2L 3G1, Canada
}

Received: 5 June 2011 - Published in The Cryosphere Discuss.: 5 July 2011

Revised: 3 October 2011 - Accepted: 6 October 2011 - Published: 20 October 2011

\begin{abstract}
Lakes comprise a large portion of the surface cover in northern North America, forming an important part of the cryosphere. The timing of lake ice phenological events (e.g. break-up/freeze-up) is a useful indicator of climate variability and change, which is of particular relevance in environmentally sensitive areas such as the North American Arctic. Further alterations to the present day ice regime could result in major ecosystem changes, such as species shifts and the disappearance of perennial ice cover. The Canadian Lake Ice Model (CLIMo) was used to simulate lake ice phenology across the North American Arctic from 1961-2100 using two climate scenarios produced by the Canadian Regional Climate Model (CRCM). Results from the 1961-1990 time period were validated using 15 locations across the Canadian Arctic, with both in situ ice cover observations from the Canadian Ice Database as well as additional ice cover simulations using nearby weather station data. Projected changes to the ice cover using the 30-year mean data between 1961-1990 and 2041-2070 suggest a shift in break-up and freeze-up dates for most areas ranging from 10-25 days earlier (break-up) and 0-15 days later (freeze-up). The resulting ice cover durations show mainly a 10-25 day reduction for the shallower lakes ( 3 and $10 \mathrm{~m}$ ) and 10-30 day reduction for the deeper lakes $(30 \mathrm{~m})$. More extreme reductions of up to 60 days (excluding the loss of perennial ice cover) were shown in the coastal regions compared to the interior continental areas. The mean maximum ice thickness was shown to decrease by $10-60 \mathrm{~cm}$ with no snow cover and $5-50 \mathrm{~cm}$ with snow cover on the ice. Snow ice was also shown to increase through most of the study area with the exception of the Alaskan coastal areas.
\end{abstract}

Correspondence to: L. C. Brown

(lcbrown@uwaterloo.ca)

\section{Introduction}

Lakes are a major feature across northern North America, forming an important part of the cryosphere, with their ice cover both playing a role in and responding to climate variability. Future changes in ice cover conditions due to changing climate conditions could impact the role of lakes on energy, water and biogeochemical processes in cold regions as well as socio-economic impacts in terms of transportation (ice roads) and recreation.

Both long-term and short-term trends have been identified in ice phenology records and are typically associated with variations in air temperatures, while trends in ice thickness tend to be associated more with changes in snow cover (Brown and Duguay, 2010). Generally, lake ice records show trends towards earlier break-up, and later freeze-up (Northern Hemisphere: Magnuson et al., 2000; Europe: e.g. Blenckner et al., 2004; Korhonen, 2006; Palecki and Barry, 1986; Weyhenmeyer et al., 2004; Livingstone, 1999); North American Laurentian Great Lakes region: e.g. Jensen et al., 2007; Johnson and Stefan, 2006; Anderson et al., 1996). However, the statistical significance and magnitude of the trends varies by location and time scale examined (see Brown and Duguay, 2010).

Throughout Canada, from 1951-2000, trends toward earlier water-clear-of-ice dates have been observed for many lakes during the latter part of the 20th century, but complete freeze over dates have shown few significant trends over the same period (Duguay et al., 2006; Latifovic and Pouliot, 2007). Changes in the ice regimes of typically perennially ice-covered lakes on northern Ellesmere Island (Nunavut, Canada) have been related to shifts in the climate regimes in that area and shown to have changed from infrequent to more frequent summer ice loss (Mueller et al., 2009). Past changes to lake ice regimes have also been inferred in the arctic using proxy methods such as diatoms (Smol, 1983, 1988; Douglas and Smol, 1999; Smol et al., 2005; Keatley et al., 2008) and sediment records (Tomkins et al., 2009).

Published by Copernicus Publications on behalf of the European Geosciences Union. 
Snow is a very important influencing factor for lake ice. Once the ice has formed, snow accumulation on the ice surface slows the growth of ice below due to the insulating properties as a result of the lower thermal conductivity (thermal conductivity of snow, $0.08-0.54 \mathrm{Wm}^{-1} \mathrm{~K}^{-1}$ versus $2.24 \mathrm{Wm}^{-1} \mathrm{~K}^{-1}$ for ice, Sturm et al., 1997). Conversely, the mass of the snow can also change the composition of the ice by promoting snow ice development, and hence influence the thickness of the ice cover (Korhonen, 2006; Brown and Duguay, 2011).

Recent work using a combination of several datasets by Brown et al. (2010) showed a reduction of the spring snow cover extent throughout the pan-arctic from 1967-2008. Specifically for the North American Arctic, they found a $12 \%$ reduction of mean snow cover extent in May and a $31 \%$ reduction in June. Additionally, Tedesco et al. (2009) using passive microwave data, found that the melt season for arctic snow has decreased by 0.6 days $\mathrm{yr}^{-1}$ from 1978 2008. Future climate predictions using the Arctic Climate Impact Assessment (ACIA) model ensemble also suggests the greatest changes to the arctic snow cover will occur during the spring (ACIA, 2005). Increasing temperatures reduce the amount of snow in a region by decreasing the fraction of precipitation that falls as snow and also by increasing snowmelt, however, increasing precipitation could counteract this (Räisänen, 2007). The complex interactions between increasing temperatures and increasing precipitation vary by region but climate model predictions for the 21 st century tend to show shorter snow cover durations, with increased amounts of snow water equivalent in the colder northern regions of North America (Räisänen, 2007; Brown and Mote, 2009). Several studies have examined the trends in the climate of the North American Arctic, typically showing warming temperatures and increased precipitation (e.g. Zhang et al., 2007; Kaufmann et al., 2009) and those trends are predicted to continue with future climate scenarios (e.g., ACIA, 2005; Bonsal and Kochtubajda, 2009). From a hydrological perspective little work has been done for this region examining future changes, however, GCMs have been used in combination with hydrological models to predict changes within a small headwater basin (Pohl et al., 2007) and the larger Liard Basin (Woo et al., 2008; Thorne, 2011). River ice duration by 2050 for most of Canada is estimated to be approximately 20 days shorter than 1961-1990, based on projected changes to the $0^{\circ}$ isotherm (Prowse et al., 2007). In the Peace-Athabasca Delta (western end of Lake Athabasca) the ice cover is estimated to be up to $20 \%$ thinner and with a reduced duration of 2-4 weeks by 2071-2099, with most of the reduction being attributed to changes in break-up (Beltaos et al., 2006). Sea ice extent is also predicted to decrease with future climates (Holland et al., 2006). Changes to the sea ice within the Canadian Arctic Archipelago (CAA) for 2041-60 are predicted to show little change in wintertime ice concentrations, with summer ice concentrations decreasing by $45 \%$ and the thickness decreasing by $17 \%$ in the winter and by
$36 \%$ in summer (Sou and Flato, 2009).

Many studies have examined how lake ice might respond to changes in both temperature and precipitation, and sensitivity analysis has shown that ice phenology is most sensitive to changes in air temperatures while ice thickness is more sensitive to snow cover (e.g., Vavrus et al., 1996; Ménard et al., 2002; Duguay et al., 2003; Gao and Stefan, 2004; Williams et al., 2004; Morris et al., 2005) (see Brown and Duguay, 2010 for a detailed comparison). While most work involving ice cover changes has been done for specific locations, Walsh et al. (1998) produced gridded ice phenology for the entire Northern Hemisphere using historical 1931-1960 mean climate data to create the first wide-scale examination of lake ice phenology. A recent study using climate model output examining possible changes to the lake ice regime in North America from $40^{\circ} \mathrm{N}$ to $75^{\circ} \mathrm{N}$ under future climates suggests break-up will advance by $10-20$ days, while freezeup will be delayed by $5-15$ days, resulting in a reduction of the ice cover duration by 15-35 days (Dibike et al., 2011).

In situ data is very sparse throughout northern North America and the majority of the climate stations in the Arctic are typically confined to relatively accessible areas of the mainland or coastal areas in the islands. The use of reanalysis data or climate model output data to drive numerical lake ice models provides the ability for wide-scale assessments of ice cover, as well as the ability to produce predictions of future ice conditions (Duguay et al., 2007; Dibike et al., 2011). The aim of this paper is to create gridded ice phenology data for North America (greater than $58^{\circ} \mathrm{N}$ ) using input data from the Canadian Regional Climate Model (CRMC) both for present day climate as well as future simulation, while highlighting the importance of snow cover on the potential changes to the lake ice regimes.

\section{Study area and methodology}

\subsection{Study area}

Canada and Alaska (USA), north of $58^{\circ}$ latitude are dominated by discontinuous or continuous permafrost except at the southern reaches of the Yukon and Northwest Territories (NWT), and northern part of the provinces of British Columbia and Alberta (Fig. 1). The area encompasses mainly subarctic and arctic climate, where the temperatures can reach up to $25^{\circ} \mathrm{C}$ in the summer in the interior continental areas (e.g. Yellowknife, NWT) to below $-40^{\circ} \mathrm{C}$ in the winter throughout most of the area. Mean annual temperatures range from $4^{\circ} \mathrm{C}$ in the coastal areas of Alaska, to $-18^{\circ} \mathrm{C}$ on Ellesmere Island. Precipitation varies greatly across the continent with over $3000 \mathrm{~mm}$ near the northern coast of the Gulf of Alaska; the interior regions receiving 200-400 mm (higher amounts in the Yukon and NWT mountain areas); decreasing to less than $200 \mathrm{~mm}$ per year in the Canadian Arctic Archipelago (CAA). Snow cover amounts 


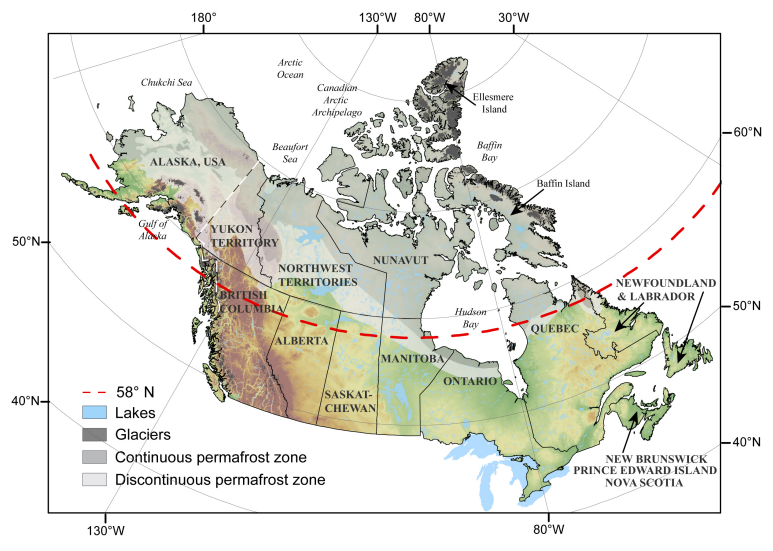

Fig. 1. Canada with provincial and territorial boundaries and the state of Alaska (USA), highlighting the area above $58^{\circ} \mathrm{N}$ used for this study. Also shown are areas of permafrost and glacier.

through most of the region range from $30-50 \mathrm{~cm}$ (higher in the mountains) with less than $30 \mathrm{~cm}$ in the western parts of the CAA.

Many mountainous areas are present in the study region: The Western Cordillera extending up the west coast through British Columbia and Alaska with the Alaska Range and the Brooks Range to the north; and the Arctic Cordillera spanning most of the northern areas of the CAA. Across the interior plains and the northern parts of the Canadian Shield is the boreal forest while tundra extends to the north of the tree line.

Many large lakes $\left(>400 \mathrm{~km}^{2}\right)$ are situated north of $58^{\circ} \mathrm{N}$ (e.g. Nettelling Lake, Amadjuak Lake, Baker Lake) as well as the Northern Great Lakes (Great Bear Lake and Great Slave Lake). Lakes in the northern boreal and tundra areas are numerous, with an estimated coverage in the Arctic and Subarctic regions of North America reaching up to 15-40\% depending on the location (Duguay et al., 2003).

\subsection{Lake ice model}

The model used is the Canadian Lake Ice Model (CLIMo), a one-dimensional thermodynamic model used for freshwater ice cover studies (e.g. Ménard et al., 2002; Duguay et al., 2003; Jeffries et al., 2005, Morris et al., 2005) capable of simulating ice on and off, thickness and composition of the ice cover (clear or snow ice). CLIMo has been shown to perform very well at simulating lake ice phenology when using input data that well represents the climate for the lake, for example from nearby meteorological towers (Duguay et al., 2003; Jeffries et al., 2005; Brown and Duguay, 2011). CLIMo has been modified from the onedimensional sea ice model of Flato and Brown (1996), which was based on the one-dimensional unsteady heat conduction equation, with penetrating solar radiation, of Maykut and Untersteiner (1971), i.e.

$\rho C_{p} \frac{\partial T}{\partial t}=\frac{\partial}{\partial z} k \frac{\partial T}{\partial z}+F_{\mathrm{sw}} I_{o}(1-\alpha) K e^{-k z}$

where $\rho\left(\mathrm{kg} \mathrm{m}^{-3}\right)$ is the density, $C_{p}\left(\mathrm{~J} \mathrm{~kg}^{-1} \mathrm{~K}^{-1}\right)$ is the specific heat capacity, $T(\mathrm{~K})$ is the temperature, $t(\mathrm{~s})$ is the time, $k\left(\mathrm{Wm}^{-1} \mathrm{~K}^{-1}\right)$ is the thermal conductivity, $z(\mathrm{~m})$ is the vertical coordinate, positive downward, $F_{\mathrm{sw}}\left(\mathrm{Wm}^{-2}\right)$ is the downwelling shortwave radiative energy flux, $I_{o}\left(\mathrm{Wm}^{-2}\right)$ is the fraction of shortwave radiation flux that penetrates the surface, $\alpha$ is the surface albedo, and $K$ is the bulk extinction coefficient for penetrating shortwave radiation.

From this, the surface energy budget can then be calculated:

$F_{o}=F_{\mathrm{lw}}-\varepsilon \sigma T^{4}(0, t)+(1-\alpha)\left(1-I_{o}\right) F_{\mathrm{sw}}+F_{\mathrm{lat}}+F_{\mathrm{sens}}$

where $F_{o}\left(\mathrm{Wm}^{-2}\right)$ is the net downward heat flux absorbed at the surface, $\varepsilon$ is the surface emissivity, $\sigma$ is the StefanBoltzmann constant $\left(5.67 \times 10^{-8} \mathrm{Wm}^{-2} \mathrm{~K}^{-4}\right), F_{\mathrm{lw}}\left(\mathrm{Wm}^{-2}\right)$ is the downwelling longwave radiative energy flux, $F_{\text {lat }}$ $\left(\mathrm{Wm}^{-2}\right)$ is the downward latent heat flux, and $F_{\text {sens }}\left(\mathrm{Wm}^{-2}\right)$ is the downward sensible heat flux (Ménard et al., 2002, Jeffries et al., 2005).

CLIMo includes a fixed-depth mixed layer in order to represent an annual cycle. When ice is present, the mixed layer is fixed at the freezing point and when ice is absent, the mixed layer temperature is computed from the surface energy budget and hence represents a measure of the heat storage in the lake. The water column of shallow lakes is typically wellmixed and isothermal from top to bottom during the ice-free period, permitting the mixed layer depth to be a good approximation of the effect of lake depth leading to autumn freezeup (Duguay et al., 2003). While warming lake temperatures from longer ice free seasons could alter the lake stratification (e.g. Kvambekk and Melvold, 2010; Mueller et al., 2009) an assumption was made that the mixed layer remained constant in the future simulations. In order to represent potential changes to the mixed layer a lake model such as the Freshwater Lake model (FLake: Mironov, 2008) could be used to provide mixed layer information for CLIMo (Kheyrollah Pour et al., 2011).

The snow layer (if present) is represented as a single layer in CLIMo. While recent work has highlighted some advantages to multi-layer snow models (e.g. Chung et al., 2010 who coupled a snow model (SNTHRM) to a sea ice model) when provided realistic on-ice snow densities, CLIMo has been shown to simulate the on-ice snowpack depth and melt well compared to observations (Brown and Duguay, 2011). Snow ice is created by the model if there is a sufficient amount of snow to depress the ice surface below the water level. The added mass of the water filled snow pores (slush) is added to the ice thickness as snow ice.

The albedo parameterization in CLIMo is based mainly on surface type (ice, snow or open water), surface temperatures 


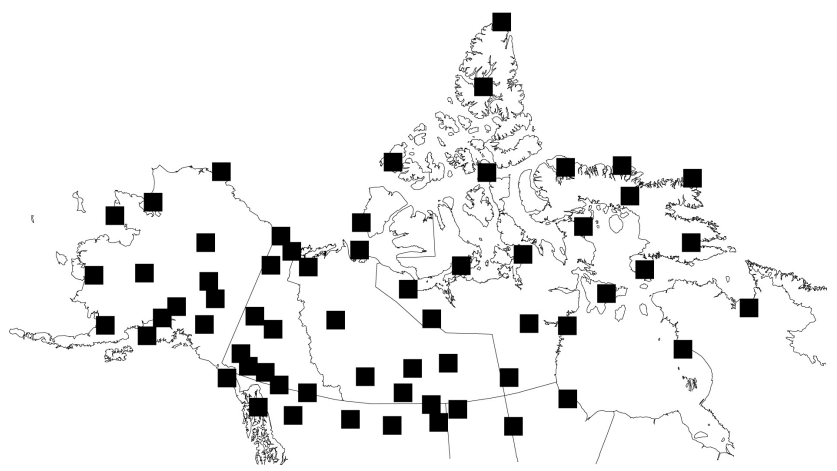

Fig. 2. Locations of stations used for CRCM temperature adjustment; 15 stations within Alaska and 47 stations within Canada.

(melting vs. frozen) and ice thickness, with no distinction regarding ice composition. A more detailed description of CLIMo can be found in Duguay et al. (2003).

\subsection{Forcing data}

CLIMo was driven by climate model output from the Canadian Regional Climate Model (CRCM 4.2.0) (45 km true at $60^{\circ} \mathrm{N}$ ) provided by Consortium Ouranos. CRCM is a limited-area model, originally developed at Université du Québec à Montréal (UQAM), driven at the boundaries by GCMs or reanalysis data. CRCM uses the Canadian LAnd Surface Scheme (CLASS 2.7; Verseghy, 1991; Verseghy et al., 1993) to describe the water and energy exchanges between land surface and atmosphere (Music and Caya, 2007). For a detailed description of CRCM see Caya and Laprise (1999) and Laprise (2008).

Two CRCM scenarios were used, both spanning from 1961-2100, driven at the boundaries with the Canadian Global Climate Model (CGCM 3.1/T47 member 4 (scenario 1) and member 5 (scenario 2)) following the IPCC Special Report on Emission Scenarios A2 green-house-gas scenario, of continually increasing $\mathrm{CO}_{2}$ emissions. The two scenarios are the same except with a slight perturbation to the initial GCM conditions which allows the climate to evolve slightly differently, providing some insight into the interannual variability in the climate simulations. CGCM data is produced by the Canadian Centre for Modelling and Analysis (CCCma). Daily data from each scenario consisted of $2 \mathrm{~m}$ screen temperature, humidity (specific humidity converted to relative humidity using a calculated saturated vapour pressure as a function of temperature (Beljaars et al., 1989) and a fixed air pressure of $1015 \mathrm{mb}$ ), wind speed, water equivalent of snow, snow density and cloud cover amounts.

A temperature bias has been previously identified in the CRCM data (Plummer et al., 2006; Gagnon et al., 2009) and was an average of $4{ }^{\circ} \mathrm{C}$ below the observed station temperatures, varying seasonally up to $14{ }^{\circ} \mathrm{C}$ too cold during the spring in some areas. The use of reanalysis data (e.g. NCEP-
NCAR, ECMWF) is limited in this region as previous studies have found these data sets to have cold biases as a result of the large grid cells representing the glaciated and mountainous areas more-so than the channels between the islands (Sou and Flato, 2009) and hence not representative of the low-lying or coastal areas where lakes would more likely be situated. Instead, a bias correction was done using temperature data from the Adjusted and Homogenized Canadian Climate Data (AHCCD) available from Environment Canada, which is a database of homogenized and long-term temperature time series specifically designed for climate change analysis over Canada (Vincent and Gullet,1999; Vincent, 1998; Vincent et al., 2002). 47 stations were available across the Canadian north and an additional 15 weather stations from Alaska were added for the bias correction (Fig. 2). While this method of bias correction is adequate for the majority of the study area, correcting the large bias in the mountainous Ellesmere Island areas using coastal station data (Alert) could potentially introduce a warm bias over the glaciated mountains. Conversely, since this study aims to examine changes in the lake ice cover, the adjusted temperature data would be suitable to represent the areas where lakes would be more likely to be situated (e.g. lowland areas, valleys, rather than in high altitude glaciated areas). The mean monthly bias was determined from the 1961-1990 data and then adjusted accordingly. Snow amounts from the CRCM scenarios were compared to station data (see Sect. 3.1) and were found to be suitably comparable. Other variables play a lesser role in the model and no bias correction was undertaken. An assumption was made that the bias present from 1961-1990 is consistent into the future.

\subsection{In situ data}

Fifteen lakes were selected as validation sites for the CRCM simulations (Fig. 3, Table 1). Each lake chosen has observation data available for ice break-up and freeze-up in the Canadian Ice Database (CID) during the contemporary climate (1961-1990). The 1961-1990 climate mean was chosen rather than the more recent 1979-2000 climate mean as the earlier set coincides with the peak years of in situ lake ice observations. The CID is a national historical database of in situ ice cover (lake ice, river ice, landfast sea ice) from 1822 for 757 sites across Canada (259 Lakes) (Lenormand et al., 2002). For clarity, the two unnamed lakes will be referred to by their nearest communities (Mould Bay and Sachs Harbour). To assess the performance of the CRCM simulations of freeze/break-up, simulations were also run for each of the validation sites using data from nearby weather stations operated by the Meteorological Service of Canada (MSC) (air temperature, relative humidity, wind speed, and cloud cover). Snow depth and density were obtained from the Canada Snow CD (MSC, 2000), a database of quality controlled and reconstructed snow data from Meteorological Service of Canada stations throughout Canada (Brown 


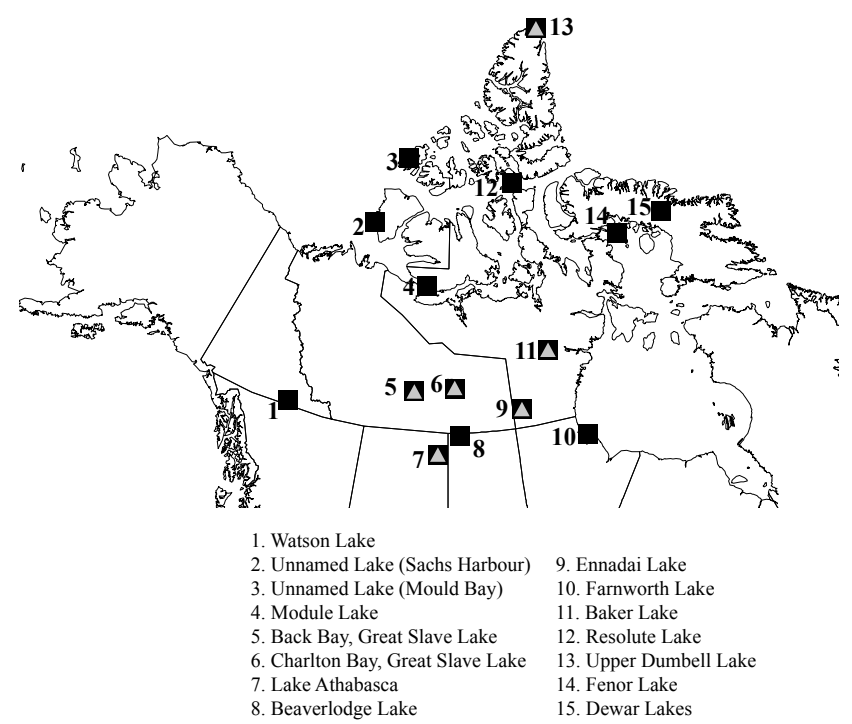

Fig. 3. Lakes used as validation sites for the model simulations. Squares represent the lakes used for ice phenology validation, triangles represent the lakes where snow depth on ice and ice thickness data was also available.

and Braaten, 1998). Snow density was obtained as a seasonal average from bi-weekly gridded snow density normals, created from snow course data and interpolated to a $200 \mathrm{~km}$ grid (MSC, 2000). Six of the selected validation sites had on-ice snow depths measurements recorded by the Canadian Ice Service (CIS) as part of the Canadian Ice Thickness Program (http://www.ec.gc.ca/glaces-ice/default. asp?lang=En $\backslash \& n=E 1 B 3129 D-1)$. Ice thickness and snow depths are available for 195 Lake/River/Sea ice sites throughout Canada from 1947 to present, with varying completeness of years. Snow depths on the lake ice surface were compared with snow depths at the MSC stations and the corresponding CRCM tile in order to examine the effects of snow depth on the ice cover simulations.

Table 1 provides a summary of the available observation data from the validation lakes, along with the years of available meteorological data and on-ice snow depths where available. A statistical comparison was done for the validation results using the Mean Bias Error (MBE) or Absolute Error (AE).

\subsection{Simulations}

In order to account for redistribution of snow across the ice surface, simulations for the North American Arctic were run using the CRCM data with both a full snow cover and no snow cover (see Sect. 3.1 for details). Three sets of simulations were run with respect to mixing depth: $3 \mathrm{~m}$ (to represent shallow lakes, e.g. in the North Slope area of Alaska; the Hudson Bay Lowlands), $10 \mathrm{~m}$ (to represent medium deep lakes, near-shore areas where observations would be taken on larger lakes, or lakes of unknown depth following Samuelsson et al., 2010) and $30 \mathrm{~m}$ (to represent large, deep lakes).

While the pan-arctic simulations were run with two possible snow covers (full snow cover or no snow cover), the validation lakes were each simulated separately in order to obtain the best representation possible. The percentage of snow-on-ice to snow-on-land was determined when possible from the CIS data, or was estimated based on best fit to observations when no measurements were available. To compare how well the CRCM data performed for the in situ lakes, the CRCM snow data was adjusted in the same manner for the tiles over each validation lake and additional simulations were run.

\section{Results}

\subsection{Comparison of snow cover on the lakes}

Realistic representation of snow cover on a lake ice surface is important for accurate simulation of ice evolution (Brown and Duguay, 2011) because of snow's important insulating role and contribution to snow ice growth. Redistribution of the snow across the lake ice surface can result in a non-uniform snow cover, typically less than what would be measured nearby on-land. For example, in northern Alaska, the ratio of snow-on-ice over the lakes to snow-on-land was found to be and average of 56\% (Sturm and Liston, 2003). In order to represent the range of potential snow conditions on the lake ice surface, simulations are run with a "full snow cover" to represent $100 \%$ of the snowfall accumulating on the ice, as well as a "no snow cover" simulation to represent the opposite conditions. Table 2 presents the comparison of the snow cover between the CRCM data sets with respect to the measured snow at the MSC stations nearest to the lakes where on-ice snow measurements were available. Although it is not advised to compare a CRCM tile with a weather station (Gagnon et al., 2009) an assessment of the amounts of snow in each data set is important to determine the ability of the CRCM tile to represent the snow cover of the lakes within it.

The ratio of on-ice snow depth to on-shore snow depth at the MSC stations were all less than 1 (Table 2). The lakes have an average of $41-82 \%$ of the snow measured at the MSC stations on their surface, with the exception of Baker Lake, which had only $9 \%$ of the recorded snow measured on the ice surface. The CRCM tiles over these lakes had fairly comparable ratios between them, and were within 80-122\% of the snow amounts measured at the MSC stations, excluding Upper Dumbell Lake. CRCM snow cover in the region near Upper Dumbell Lake is consistently overestimated due to perpetual snow cover in the CRCM data after the snow has melted at the station. The CRCM tile over Upper Dumbell Lake covers both land and ocean; however, the climate in this tile is more likely representative of the surrounding high altitude regions. 
Table 1. Summary of the lake ice observation data, corresponding climate station and the years used.

\begin{tabular}{lllll}
\hline $\begin{array}{l}\text { Lake Observations } \\
\text { (CID) }\end{array}$ & $\begin{array}{l}\text { Nearby Climate } \\
\text { Station (MSC) }\end{array}$ & Years & $\begin{array}{l}\text { Years of ice } \\
\text { observations } \\
\text { Break-up/ } \\
\text { Freeze-up }\end{array}$ & $\begin{array}{l}\text { Years of } \\
\text { Snow Depth } \\
\text { on ice }\end{array}$ \\
\hline Watson Lake & Watson Lake & $1961-1990$ & $28 / 25$ & \\
Unnamed Lake & Sachs Harbour & $1961-1986$ & $18 / 18$ & \\
Unnamed Lake & Mould Bay & $1961-1990$ & $18 / 21$ & \\
Module Lake & Kugluktuk & $1980-1990$ & $7 / 9$ & \\
Back Bay & Yellowknife & $1961-1990$ & $28 / 27$ & $1961-1990$ \\
Charlton Bay & Fort Reliance & $1961-1990$ & $26 / 29$ & $1961-1990$ \\
Lake Athabasca & Fort Chipewyan & $1968-1990$ & $20 / 17$ & $1962-1990$ \\
Beaverlodge Lake & Uranium City & $1963-1982$ & $20 / 16$ & $1961-1979$ \\
Ennadai Lake & Ennadai Lake & $1961-1979$ & $19 / 19$ & $1961-1990$ \\
Farnworth Lake & Churchill & $1961-1990$ & $22 / 22$ & \\
Baker Lake & Baker Lake & $1961-1990$ & $29 / 29$ & $1961-1990$ \\
Resolute Lake & Resolute & $1961-1990$ & $10 / 18$ & \\
Upper Dumbell Lake & Alert & $1961-1990$ & $3 / 24$ & \\
Fenor Lake & Hall Beach & $1961-1990$ & $4 / 6$ & \\
Dewar Lakes & Dewar Lakes & $1961-1990$ & $21 / 23$ & \\
\hline
\end{tabular}

Table 2. Ratio of snow depths measured on-ice and snow depth from the CRCM data with respect to the amounts measured at the MSC weather stations.

\begin{tabular}{lccr}
\hline Lake (MSC Station) & $\begin{array}{c}\text { Ratio of on-ice snow } \\
\text { depth to MSC station }\end{array}$ & \multicolumn{2}{c}{$\begin{array}{c}\text { Ratio of CRCM } \\
\text { snow depth to } \\
\text { nearest MSC station }\end{array}$} \\
\hline & & & S 1 2 \\
\cline { 3 - 4 } Back Bay, GSL (Yellowknife) & 0.68 & 0.89 & 1.04 \\
Charlton Bay, GSL (Fort Reliance) & 0.48 & 0.80 & 0.88 \\
Lake Athabasca (Fort Chipewyan) & 0.41 & 0.83 & 0.83 \\
Ennadai Lake & 0.67 & 1.21 & 1.22 \\
Baker Lake & 0.09 & 0.85 & 0.81 \\
Upper Dumbell Lake & 0.82 & 2.34 & 2.35 \\
\hline
\end{tabular}

\subsection{Ice cover during 1961-1990 climate}

The two CRCM scenarios are similar for the contemporary climate years (1961-1990). The similar input data results in similar simulated ice cover patterns with the primary difference between them occurring in the areas predicted to have perennial ice cover. The ice cover figures produced for the 1961-1990 climate use scenario 1 and are meant to represent hypothetical lakes at the given depths $(3,10$ and $30 \mathrm{~m})$, since many different lakes sizes and shape could exist within a given grid cell.

\subsubsection{Ice cover duration 1961-1990}

Break-up of the ice cover ranges from March in the Gulf of Alaska coastal areas to August in the High Arctic (yd 102yd 241), with perennial ice cover on Ellesmere Island and other regions of the CAA; as well as northern Baffin Island with the no snow scenarios (Fig. 4). Mean break-up dates for the entire study region range from yd 162-165 for all simulations with snow cover (mean yd 163) and yd 171-174 (mean yd 172) for no snow. Both climate scenarios show break-up to be similar for all depth simulations (not shown), however changes are evident based on snow cover (mean difference of 9 days between snow and no snow cover) and are more pronounced in the high latitude areas of perennial ice cover. Freeze-up however, is dependent on the depth of the 


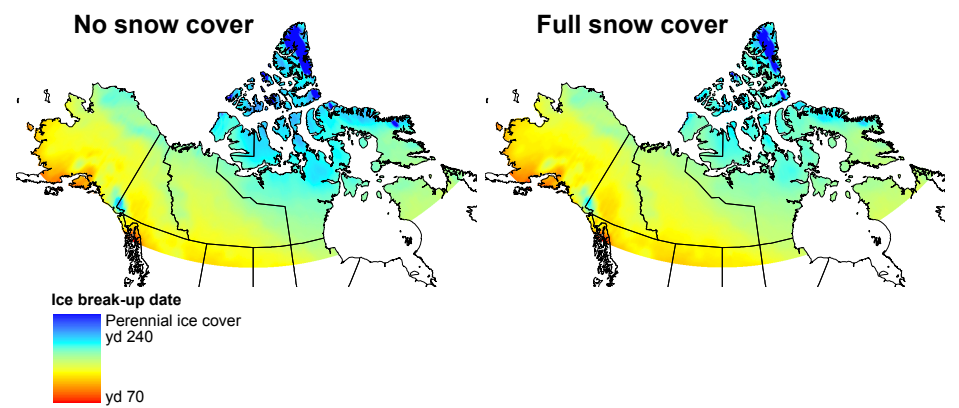

Fig. 4. Mean simulated break-up dates for 1961-1990 for hypothetical $10 \mathrm{~m}$ lakes, for both no snow and full snow scenarios.

lake rather than the snow cover scenario (Fig. 5). Freeze-up ranges from September to December (yd 245-yd 358), with a mean freeze-up date for $3 \mathrm{~m}$ lakes of yd 281, $10 \mathrm{~m}$ lakes freezing an average of 11 days later (yd 292), and $30 \mathrm{~m}$ lakes freezing an average of a further 20 days after the $10 \mathrm{~m}$ lakes (yd 313). The resulting ice cover durations vary for both depth and snow cover, ranging from 90 to 365 days (Fig. 6), with the longest ice cover duration (ICD) on shallow snowfree lakes (average of 255 days) and shortest for large snowcovered lakes (average 215 days).

In the far northern areas, break-up does not always occur on an annual basis resulting in occasional summer ice cover. All simulations encountered occasional summer ice cover on the lakes in the far northern areas, however only grid cells where no break-up occurred during the 30 year mean were designated as "perennial ice cover". Perennial ice cover is simulated the same regardless of lake depth but is slightly different between the two climate scenarios. Scenario 1 produces 40 grid cells $\left(81000 \mathrm{~km}^{2}\right)$ where perennial ice is simulated on snow-free lakes (versus $33\left(66825 \mathrm{~km}^{2}\right)$ for scenario 2) and 19 grid cells $\left(38475 \mathrm{~km}^{2}\right)$ for snow-covered lakes (versus $10\left(20250 \mathrm{~km}^{2}\right)$ for scenario 2).

\subsubsection{Ice cover thickness 1961-1990}

Lake ice thickness is known to be influenced by snow cover on the ice (e.g. Ménard et al., 2003; Morris et al., 2005; Brown and Duguay, 2011) as shown in Fig. 7, with a substantial difference between the thickness in snow-free versus snow-covered lakes. Since CLIMo uses the mixing depth rather than absolute lake depth the areas where perennial ice cover occurs continue to thicken each year and are hence, capped at $3 \mathrm{~m}$ to avoid unrealistically thick ice. Both CRCM scenarios produce similar mean maximum ice thickness (MMT) (within $2 \mathrm{~cm}$ of each other) ranging from an average of $1.91 \mathrm{~m}$ to $2.03 \mathrm{~m}$ for the snow-free scenarios, and $1.44 \mathrm{~m}$ to $1.51 \mathrm{~m}$ for the snow-covered scenarios for all depths. The difference in MMT between the snow-free and snow-covered scenarios differs by depth, with an average of $58 \mathrm{~cm}$ thicker ice for snow free $3 \mathrm{~m}$ lakes, $53 \mathrm{~cm}$ thicker ice for snow free $10 \mathrm{~m}$ lakes and $42 \mathrm{~cm}$ thicker for snow free $30 \mathrm{~m}$ lakes.
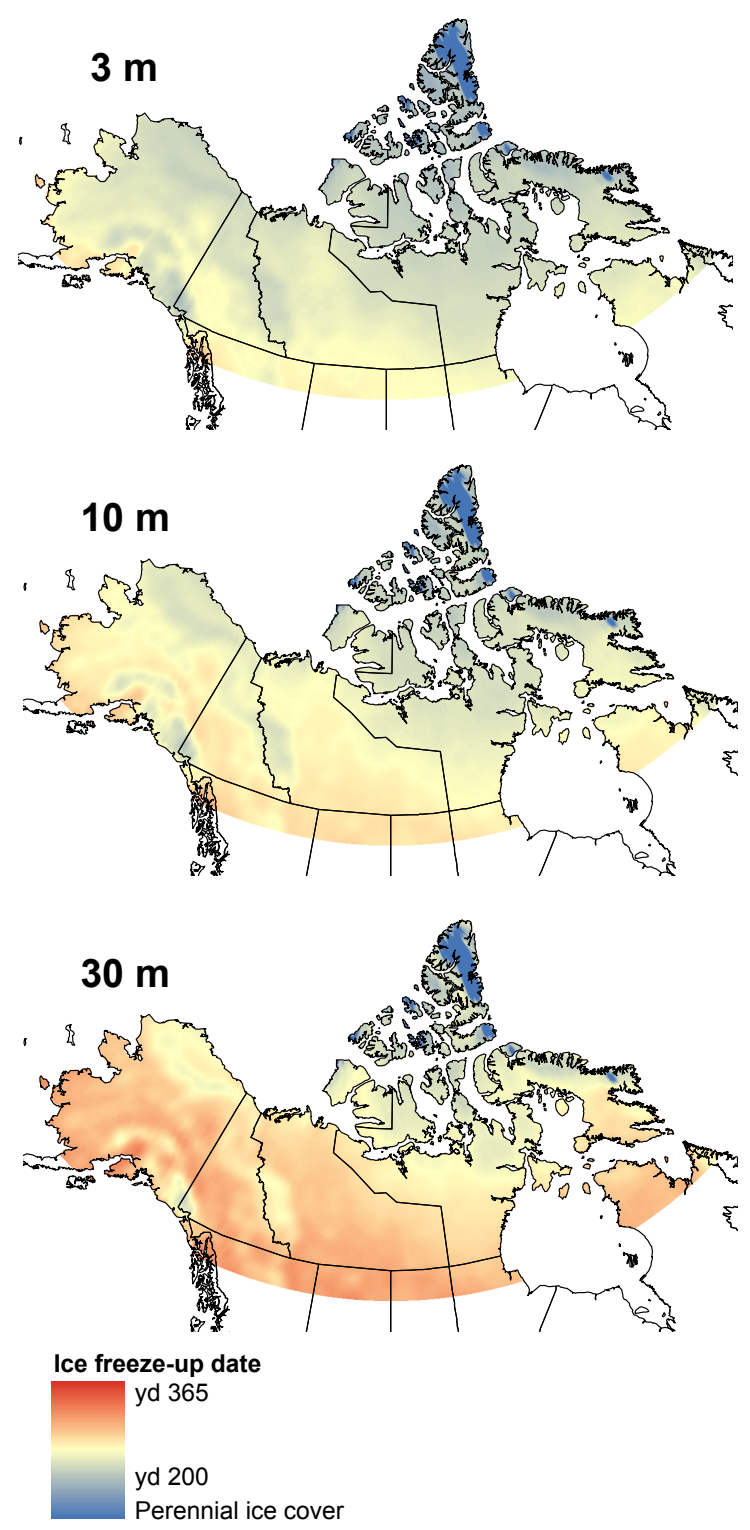

Fig. 5. Mean freeze-up dates for 1961-1990 for the three depth simulations, highlighting the effect of depth on freeze-up dates. 

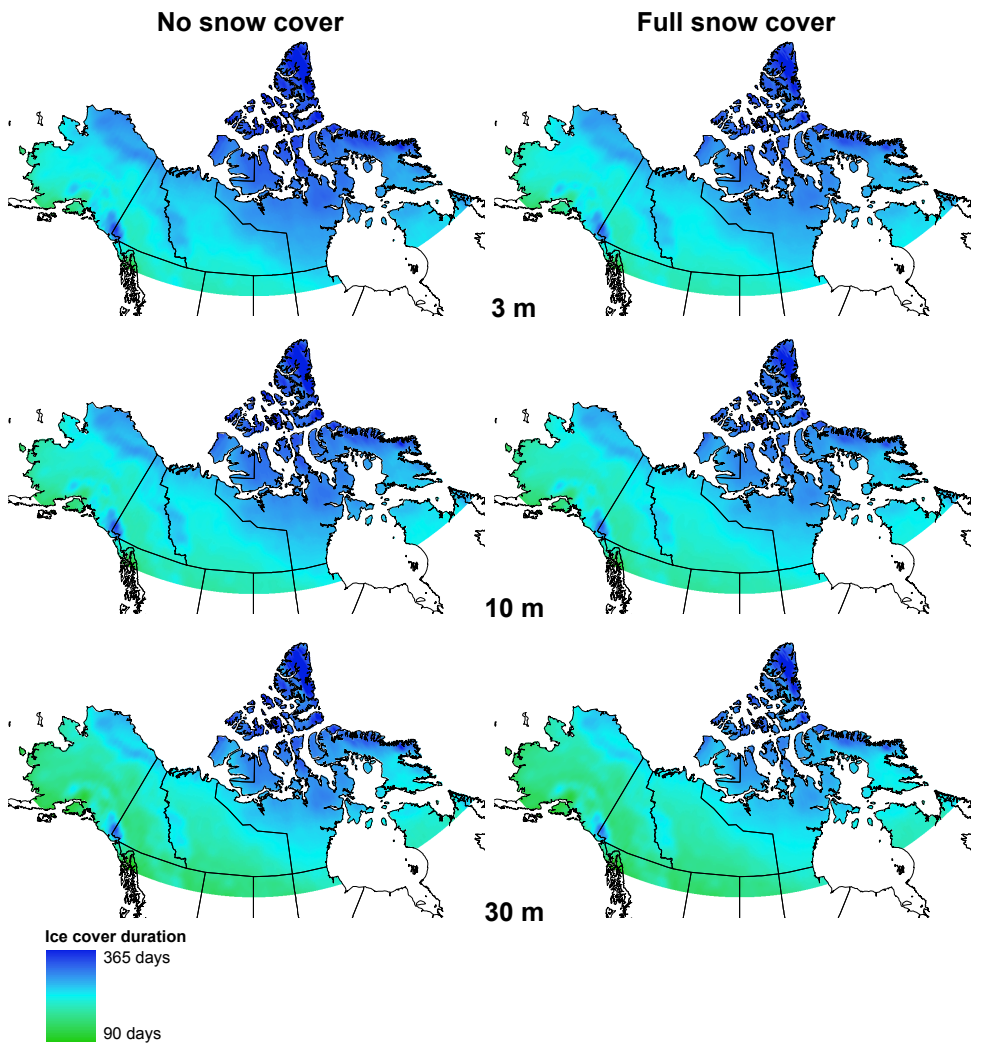

Fig. 6. Mean ice cover duration for 1961-1990 for the three depth simulations, for both the no snow and full snow scenarios.

The composition of the ice (snow ice/clear ice) can affect the strength of the ice as well as the melt rates due to albedo differences between the snow versus clear ice. Figure 8 shows the distribution of snow ice (as a ratio to total ice thickness), highlighting the areas where enough snowfall is received to depress the ice cover enough for snow ice to form. Cold temperatures and low snowfall amounts through most of the Arctic limit the amount of snow ice that forms, however throughout the mountainous areas and northern Que$\mathrm{bec} /$ southern Baffin Island some snow ice is simulated.

\subsection{Validation of ice phenology and thickness}

Validation of modelled ice phenology and thickness in Northern Canada and Alaska presents challenges as the observational network for lake ice is very sparse. Simulations using CLIMo typically compare well to observation data when run using climate data that adequately represents the lake observed (i.e. nearby weather stations) (e.g., Duguay et al., 2003; Brown and Duguay, 2010; Jefferies et al., 2005). To examine how representative the CRCM simulations are compared to observations, simulation results from the containing CRCM tiles were compared to 15 locations that had both observation data and MSC station data available. If CLIMo is not able to accurately capture the break-up/freeze-up dates using nearby MSC station data, then the same would be ex- pected of the CRCM data. This allows for distinguishing between limitations with the model rather than the CRCM data.

Table 3 presents the Mean Bias Error (MBE) for the simulations compared to observations. Looking at the MSC simulations results for the validation sites, all but six had a MBE of less than one week for the simulations compared to observations, with most being slightly early. Break-up for Mould Bay was simulated 13 days late compared to the observations, suggesting either the snow conditions are not well represented or a factor not captured by the 1-D model. Break-up for Dewar Lakes was simulated 20 days too late, again suggesting other factors that are not captured by the 1-D model - in this case likely a result of the morphometry as this locations is part of a long narrow series of lakes. Break-up at Charlton Bay and Ennadai Lake was two weeks early, however the dates vary in phase. This same early tendency for break-up was also found at Charlton Bay by Ménard et al. (2002), who suggested that this might in part be due to the sheltered location creating a favourable environment for a longer ice cover. Lake Athabasca was the only lake where freeze-up could not be adequately simulated, being 38 days too early compared to observations. The in situ data for this lake is from Fort Chipewyan, situated beside the Peace-Athabasca Delta (PAD), in a very shallow area of Lake Athabasca. The mean depth of the lake is $20 \mathrm{~m}$ however the 

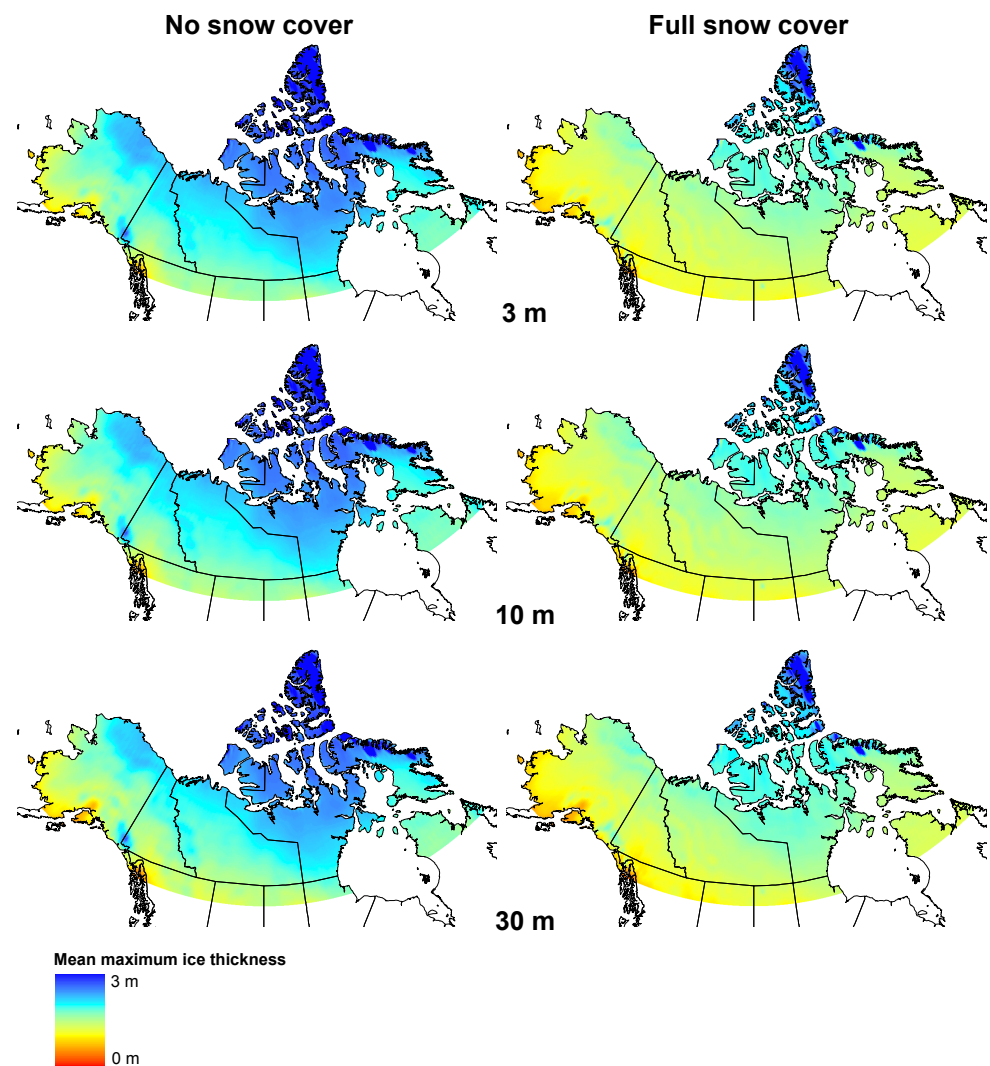

Fig. 7. Mean maximum ice thickness for 1961-1990, for three depth simulations, and both the no snow and full snow scenarios. Ice thickness capped at $3 \mathrm{~m}$ in areas where perennial ice cover growth continued due to the model structure of CLIMo.

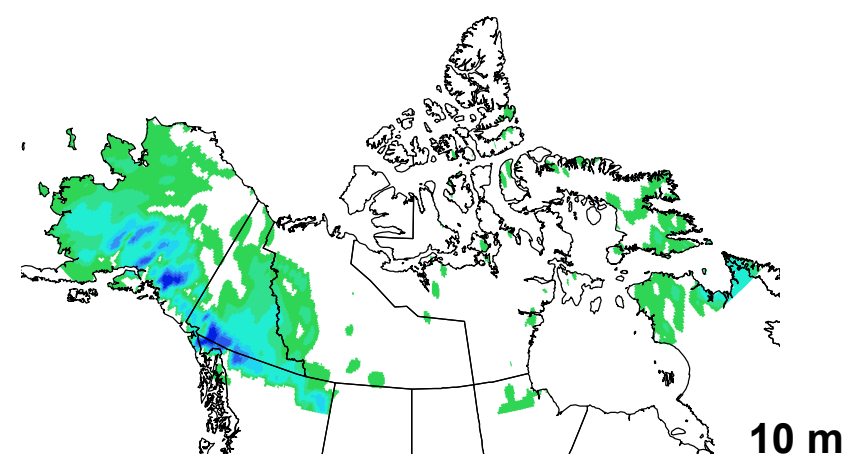

Ratio of snow ice thickness to total ice thickness

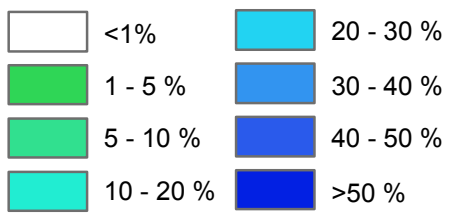

Fig. 8. Ratio of mean snow ice thickness to mean maximum ice thickness for 1961-1990. lake is $3 \mathrm{~m}$ or shallower at the western end near the PAD. The PAD is a hydrologically complicated area, where reversal of flow is known to occur (Peters and Buttle, 2010), and the additional heat inputs to the lake from the PAD and surrounding rivers in this area likely contributed to the discrepancy between the observed and simulated freeze-up. Since CLIMo usually represents freeze-up quite well a test was run adjusting the mixing depth in the simulations in order to match the observations. A mixing depth of $30 \mathrm{~m}$ was required for simulations for Lake Athabasca to match observations - suggesting that the heat added from the surround inputs to this area has the equivalent heat storage of an extra $27 \mathrm{~m}$ of water.

The CRCM simulations were within 1 week of observations for 6 of the 15 lakes simulated (Table 3). As expected from the MSC simulations, the CRCM simulations for break-up at Mould Bay and Dewar lakes were too late, and freeze-up at Lake Athabasca was too early. The five lakes with the greatest MBE for early break-up (Charleton Bay (GSL), Lake Athabasca, Ennadai Lake, Baker Lake and Resolute Lake: 10-18 days, with the exception of Resolute Lake for scenario 2, which matched observations) also had early break-up seen in the MSC simulations (5-14 days). The only anomaly between the CRCM and MSC simulations occurred at Upper Dumbell Lake for freeze-up, while the station data 
Table 3. Mean bias error (MBE) in break-up and freeze-up dates from simulations using Meteorological Service of Canada (MSC) data, CRCM scenario 1 (S1) and scenario 2 (S2) for the validation sites along with the mean observed break-up and freeze-up from the Canadian Ice Database (CID) (dates as indicated in Table 1).

\begin{tabular}{|c|c|c|c|c|c|c|c|c|c|c|}
\hline \multirow[t]{2}{*}{ Lake } & \multirow{2}{*}{$\begin{array}{l}\text { Snow } \\
\text { cover } \\
(\%)\end{array}$} & \multirow{2}{*}{$\begin{array}{l}\text { Mixing } \\
\text { Depth } \\
\text { (m) }\end{array}$} & \multicolumn{4}{|c|}{ Break-up } & \multicolumn{4}{|c|}{ Freeze-up } \\
\hline & & & CID & $\begin{array}{r}\text { MSC } \\
y d\end{array}$ & $\begin{array}{c}\mathrm{S} 1 \\
(\mathrm{MBE}\end{array}$ & $\begin{array}{r}\text { S2 } \\
\text { days) }\end{array}$ & $\begin{array}{r}\text { CID } \\
\text { yd }\end{array}$ & $\begin{array}{l}\text { MSC } \\
(\mathrm{MBE}\end{array}$ & $\begin{array}{r}\text { S1 } \\
\text { days) }\end{array}$ & $\mathrm{S} 2$ \\
\hline Watson Lake ${ }^{\mathrm{a}}$ & $0^{+}$ & 10 & 141 & 5 & 0 & -2 & 314 & 1 & 1 & 2 \\
\hline Unnamed Lake - Sachs Harbour ${ }^{\mathrm{a}}$ & $100^{\mathrm{c}}$ & 3 & 188 & 1 & 5 & 4 & 269 & 1 & -5 & -6 \\
\hline Unnamed Lake - Mould Bay ${ }^{\mathrm{a}}$ & $100^{\mathrm{c}}$ & 2 & 191 & 13 & 13 & 16 & 247 & 2 & 6 & 2 \\
\hline Module Lake & $100^{\mathrm{c}}$ & 3 & 181 & -4 & -2 & -6 & 278 & -5 & 1 & -2 \\
\hline Back Bay & 68 & 10 & 151 & -2 & -3 & -3 & 302 & 3 & 5 & 4 \\
\hline Charlton Bay & 48 & 20 & 172 & -14 & -16 & -15 & 321 & -2 & -3 & -4 \\
\hline Lake Athabasca ${ }^{b}$ & 41 & 3 & 145 & -9 & -11 & -6 & 339 & -38 & -37 & -38 \\
\hline Beaverlodge Lake ${ }^{\mathrm{a}}$ & $0^{\mathrm{c}}$ & 20 & 151 & -4 & -8 & -8 & 329 & -2 & -2 & -4 \\
\hline Ennadai Lake ${ }^{\mathrm{a}}$ & 62 & 10 & 183 & -14 & -18 & -15 & 295 & 0 & 6 & 4 \\
\hline Farnworth Lake & $0^{\mathrm{a}}$ & 2 & 171 & 0.5 & -7 & -4 & 291 & -1 & 2 & 4 \\
\hline Baker Lake & 9 & 20 & 200 & -9 & -14 & -13 & 297 & 0 & 4 & 1 \\
\hline Resolute Lake & $50^{\mathrm{a}}$ & 10 & 212 & -6 & -10 & 0 & 262 & -2 & 5 & 3 \\
\hline Upper Dumbell Lake & 82 & 15 & $218^{d}$ & & & & & -3 & 9 & 12 \\
\hline Fenor Lake ${ }^{\mathrm{a}}$ & $50^{c}$ & 10 & 203 & -5 & -3 & -5 & 280 & -3 & 4 & -1 \\
\hline Dewar Lakes ${ }^{\mathrm{a}}$ & 0 & 10 & 185 & 20 & 10 & 10 & 275 & -3 & 1 & 2 \\
\hline
\end{tabular}

\footnotetext{
${ }^{a}$ Assumed mixing depth based on most suitable fit to observations when lake depth was not available. ${ }^{b}$ Freeze up simulated poorly due to hydrological factors not captured by the 1-dimensional model. ${ }^{\mathrm{c}}$ Snow cover percentage estimated based on best fit to observations when on ice snow depth measurements not available. ${ }^{\mathrm{d}}$ Only 3 break-up observations available.
}

resulted in freeze-up being captured within 3 days of observations, CRCM simulations for scenario 1 and 2 were both over a week late.

Overall, the absolute error compared to observations for all fifteen lakes combined was 8 days for break-up and 6 days for freeze-up (4 days excluding Lake Athabasca), indicating that CLIMo produces satisfactory simulations for break/freezeup using CRCM climate data.

A comparison of mean maximum thickness (MMT) was possible at five of the validation lakes (Table 4). Simulating the ice thickness correctly is dependent on accurately representing the snow cover depth and density on the lake ice surface where the measurements were taken. Also, since the in situ thickness measurements are generally taken weekly (but not always) there is a small possibility of missing the maximum thickness during the sampling. For Back Bay (GSL) the MSC simulations had a MBE of $10 \mathrm{~cm}$ too thin, while the CRCM simulations here were $20 \mathrm{~cm}$ too thick. Ennadai Lake was also too thin with MSC $(12 \mathrm{~cm})$ however in this instance the CRCM simulations were closer to the observations ( $<4 \mathrm{~cm} \mathrm{MBE).} \mathrm{MMT} \mathrm{was} \mathrm{underestimated} \mathrm{at} \mathrm{Baker}$ Lake as well with the MSC simulations $14 \mathrm{~cm}$ too thin, and the CRCM simulations $11 \mathrm{~cm}$ too thin. Break-up was not simulated well at Charlton Bay (GSL) so the likelihood of representing the thickness well here is reduced with all simulations being too thick. The large discrepancy for the thickness of Upper Dumbell Lake for the CRCM simulations is due to the snow cover being poorly represented here (MSC simulations captured the thickness well with a MBE of $6 \mathrm{~cm}$ ).

The average absolute error for the simulated MMT compared to observations is $10 \mathrm{~cm}$ for the MSC simulations and $25 / 23 \mathrm{~cm}$ for the CRCM simulations using the best estimate for snow cover amounts. Excluding Charlton Bay where the MSC simulations did not capture the observations well (and hence CRCM would not be expected to either), and Upper Dumbell Lake where snow cover amounts are inaccurate, the average absolute error for the remaining three lakes is within $12 \mathrm{~cm}$ of observations for both scenarios.

Snow ice measurements are not recorded in the historical archives, however a study on Baffin Island near Iqaluit, Nunavut, found a $7 \%$ ratio of snow ice to maximum ice thickness during the 2005-2006 winter (Dyck, 2007). The 1961-1990 mean ratio in this area was $\sim 6 \%$.

\subsection{Ice cover during future climate}

The dominant climatic variables in terms of ice cover changes are air temperature and the snow conditions (both depth and density). The future scenario data from CRCM is driven by CGCM3 which was one of the models used in the IPCC AR4 (CMIP3) model ensemble. CGCM3 showed a greater increase in precipitation than the ensemble mean, but was near the mean in terms of temperature increase overall (Meehl et al., 2007). Spatially, comparison figures provided 
Table 4. Mean bias error in mean maximum thickness for the validation sites along with the mean maximum thicknesses (dates as indicated in Table 1).

\begin{tabular}{|c|c|c|c|c|c|c|c|c|}
\hline \multirow[t]{2}{*}{ Lake } & \multirow{2}{*}{$\begin{array}{c}\text { Snow } \\
\text { cover }(\%)\end{array}$} & \multicolumn{4}{|c|}{ Mean Maximum Ice Thickness (m) } & \multicolumn{3}{|c|}{$\operatorname{MBE}(\mathrm{m})$} \\
\hline & & CIS & MSC & S1 & S2 & MSC & S1 & $\mathrm{S} 2$ \\
\hline Back Bay (GSL) & 68 & 1.32 & 1.23 & 1.54 & 1.50 & -0.10 & 0.22 & 0.18 \\
\hline Charlton Bay (GSL) & 48 & 1.28 & 1.36 & 1.60 & 1.62 & 0.09 & 0.32 & 0.35 \\
\hline Ennadai Lake & 62 & 1.68 & 1.56 & 1.64 & 1.68 & -0.12 & -0.04 & -0.00 \\
\hline Baker Lake & 9 & 2.27 & 2.13 & 2.16 & 2.16 & -0.14 & -0.11 & -0.11 \\
\hline Upper Dumbell Lake & 82 & 1.96 & 1.90 & 2.51 & 2.48 & -0.06 & 0.55 & 0.52 \\
\hline
\end{tabular}

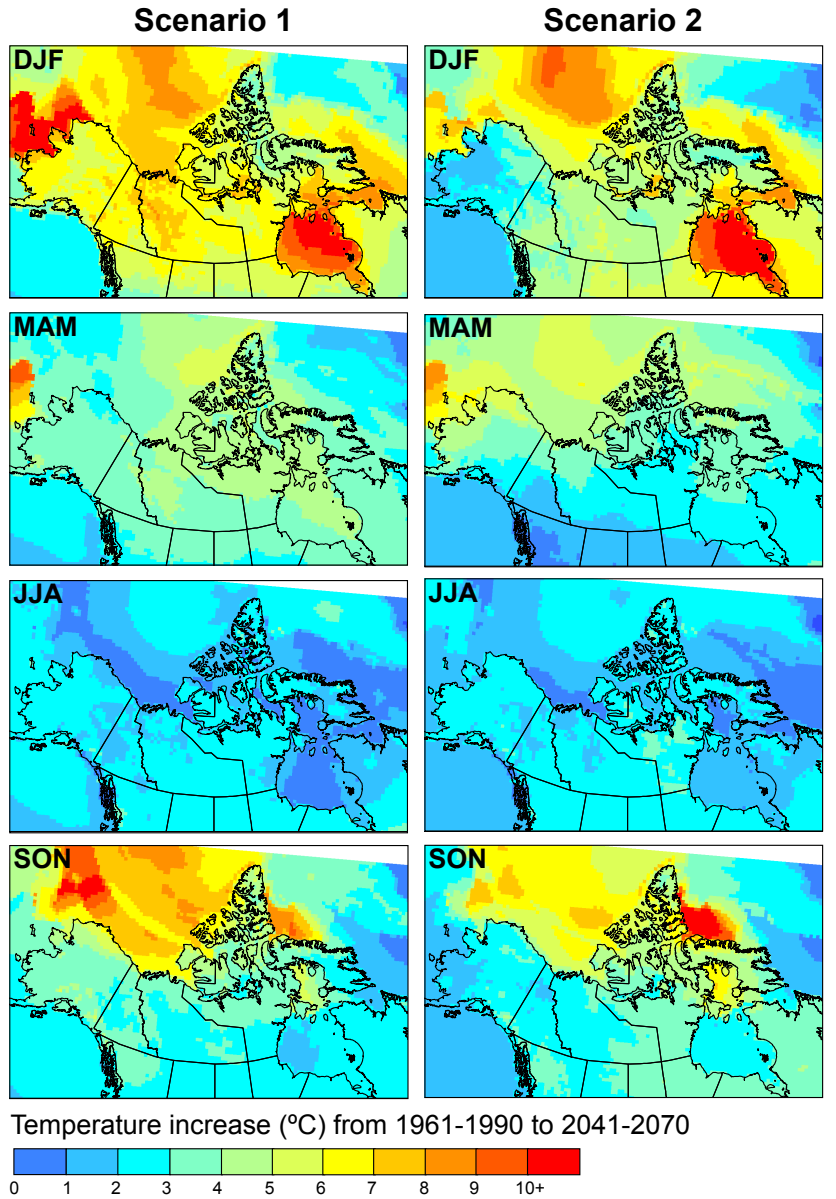

Fig. 9a. Increase in air temperature from 1961-1990 mean to 20412070 mean from the CRCM data displayed by season Winter (December, January, February), Spring (March, Aprril, May), Summer (June, July, August) and Fall (September, October, November).

on the IPCC website (IPCC, 2007) suggest CGCM3 has a larger increase in surface air temperature (1980-1999 to 2046-2065) than the ensemble mean through the Gulf of Alaska region.
Although the two CRCM scenarios begin with similar conditions and both show warming throughout (Fig. 9a), by the 2041-2070 mean they have evolved different temperature patterns. Temperatures in scenario 1 show the greatest change in the winter seasons (December, January, February) ranging from $5-9^{\circ} \mathrm{C}$ warmer over the land areas. Spring (March, April, May) shows an increase mainly in the $3-5^{\circ} \mathrm{C}$ range; summer (June, July, August) only $1-3{ }^{\circ} \mathrm{C}$, and fall (September, October, November) a $2-6^{\circ} \mathrm{C}$ change. Temperatures in scenario 2 however are cooler and show less warming to 2041-2070. Winter in scenario 2 does not have warming in the Alaskan area seen in scenario 1, and the bulk of the NWT shows less warming in the spring. Summer is quite similar for both, while fall shows less warming in Alaska.

Precipitation is expected to increase throughout the northern regions in future climate scenarios (see figures available on the NARCCAP website using similar scenario data: http://www.narccap.ucar.edu/results/ crcm-cgcm3-results.html) however, in terms of snow water equivalent (SWE) the CRCM data show spatially varying changes in the future (Fig. 9b). The majority of the northern areas show an increase of SWE consistent with increasing precipitation, however the Alaskan coastal regions and the tip of Labrador show a decrease in SWE - which would be attributed to changes from snowfall to rainfall in these areas. The two scenarios are more similar in terms of SWE than temperature, and the amount of change is mainly in the range of $\pm 10 \%$, with some winter SWE increases up to $30 \%$. Snow depths compared at the lake validation sites tend to increase, however based on a sensitivity study for Back Bay (GSL) by Ménard et al. (2003) increasing the snow depth on the ice does little to affect the ice cover duration and only slightly affect the thickness as compared to the effects of reducing the snow cover on the ice. While increased snow depth on the ice surface may not have a large impact on the duration, the ice composition is likely to be affected by the increased formation of snow-ice in the areas where the mass of the snow (or SWE) on the ice increases. 

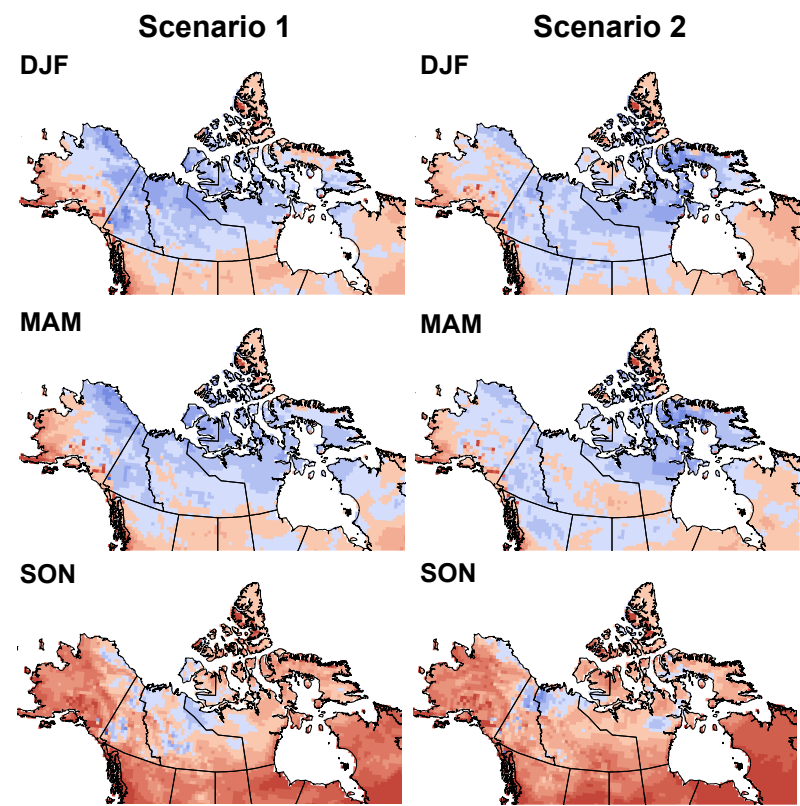

MAM

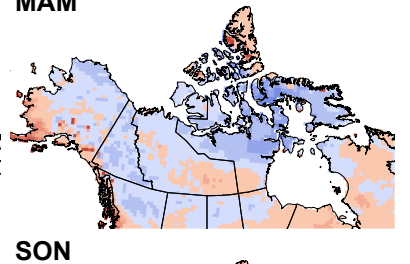

SON

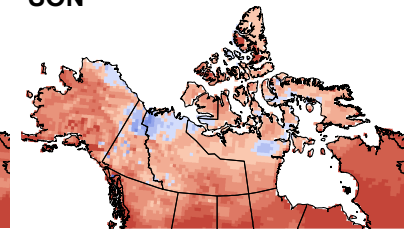

$\%$ change of snow water equivalent from 1961 - 1990 to $2041-2070$

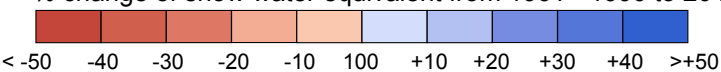

Fig. 9b. Change in snow water equivalent from 1961-1990 mean to 2041-2070 mean from the CRCM data displayed by season Winter (December, January, February), Spring (March, April, May) and Fall (September, October, November).

\subsubsection{Ice cover duration 2041-2070}

Comparing the mean break-up dates for 2041-2070 to the mean 1961-1990 dates show later break-up across the entire study area (Fig. 10a, b) with the exception of 1 small area on Baffin Island in the snow free scenario 1 simulation where the increased frequency of summer break-up resulted in a slightly earlier date. Break-up ranges from late February to mid-August (yd 51-yd 232) for all simulations, with the mean break-up date now yd 150 (151 for scenario 2) for full snow scenarios and 156 (157 for scenario 2 ) for no snow scenarios - a shift of mean break-up date 7 days earlier for the snow scenario and 14 days earlier for no snow scenario. No perennial ice cover remains in scenario 2 and only 5 grid cells remain in scenario 1 for the no snow scenarios (compared to 19 and 40 for snow/no snow in 1961-1990). Although in most areas scenario 2 is cooler than scenario 1, the far northern parts of Ellesmere and Baffin Islands where the perennial ice was located, experience warmer temperatures than scenario 1 during the winter and spring, likely contributing to the differences in the perennial ice cover.

Comparing the results from the two future scenarios can provide some insight on the possible range of dates predicted by this CRCM scenario data (Fig. 10c). Examining the snowfree scenarios, the majority of the study area has mean 20412070 break-up dates for both CRCM scenarios within 5 days of each other. Scenario 2 is mainly $0-5$ days later than scenario 1; not unexpected as slightly cooler temperatures persist in most areas of scenario 2. Only a few areas show a difference of more than 5 days between the scenarios, with a few smaller areas dispersed around the southern reaches of the study area showing 5-10 days later break-up. The northwestern coastal and southern coastal areas of Alaska (and northern British Columbia) show 10-30 days earlier break up with scenario 2. The northern and eastern parts of the CAA show earlier break-up for scenario 2, again the result of warmer temperatures in this area. The areas with greater than 30 days differences in break-up dates on Ellesmere Island result from the lack of any remaining perennial ice cover in scenario 2. For the snow-covered scenarios, break-up for the two CRCM scenarios is still mainly within 5 days, with a larger portion of the study area shifting to $0-5$ days earlier break-up, particularly in the north eastern areas.

Freeze-up for 2041-2070 now ranges from late August until the end of December (yd 240-yd 365 for scenario1 and yd 245-yd 364 for scenario 2), with mean freeze-up dates the same for both scenarios: $289(3 \mathrm{~m}), 301(10 \mathrm{~m})$ and 325 $(30 \mathrm{~m})$. Mean freeze-up dates show a shift of 6-11 days later than those from 1961-1990, less of a change than breakup. Figure $11 \mathrm{a}$ and $\mathrm{b}$ present the changes in freeze-up dates from 1961-1990 to 2041-2070. Scenario 1 has the greatest changes for freeze-up in Alaska and the High Arctic while scenario 2 has the greatest changes in the High Arctic and eastern areas (Baffin Island and northern Quebec). The areas with greater than 40 days change in freeze-up on Ellesmere Island are the areas where the perennial ice cover changed to seasonal ice cover. There are more pronounced differences between the scenarios for freeze-up than break-up (Fig. 11c). The central section of the study area is still \pm 5 days between the scenarios, however northern Quebec and Baffin Island show 5-20 days later freeze-up with scenario 2, while freezeup in Alaska is $5-10$ days earlier with some section in the shallower lakes >10days earlier (not shown).

The changes in ICD from 1961-1990 to 2041-2070 are presented in Fig. 12a and b. Scenario 1 shows a change in ICD ranging from 10 to more than 40 days shorter by 2041-2070. The areas of the most change are the Alaska coast and the High Arctic islands (25 to $>40$ days shorter ICD); and northern Quebec (20-30 days shorter ICD). The ICD throughout the rest of the region is mainly 10-25 days shorter ICD and the effect of snow cover can also be seen in the simulations, with the snow-covered simulations producing slightly less change in ICD than the snow-free simulations.

Although scenario 1 and 2 appear quite different in terms of spatial pattern (Fig. 12a, b) this is in part due to the broad 5 day categorization. Scenario 2 shows the same range of ICD changes as scenario 1 , however, there are much larger areas with less change due to the smaller changes in breakup and freeze-up. Of note here is the areas of most change - scenario 1 focusing over the Alaskan coast and scenario 2 
a) Scenario 1
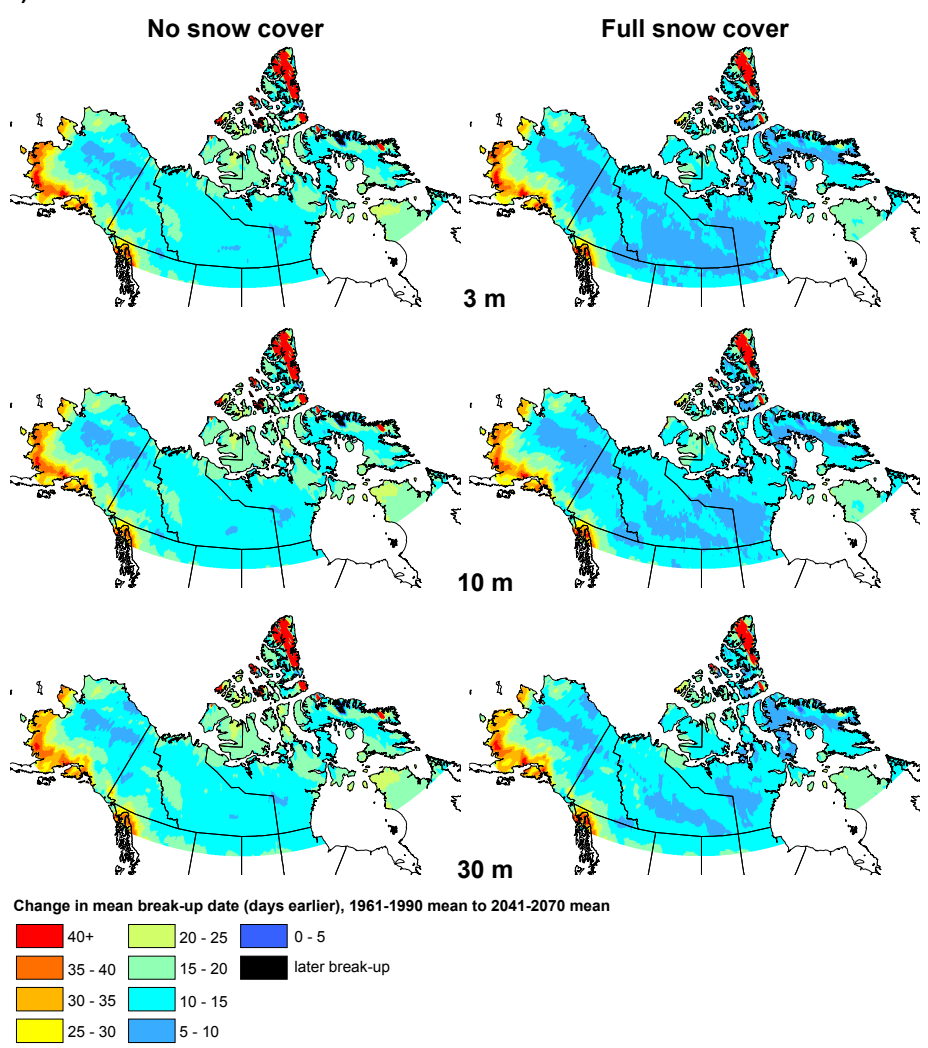

Fig. 10a. Change in mean break-up date from 1961-1990 to 2041-2070 for (a) scenario 1; (b) scenario 2; (c) the difference between the scenarios for the 2041-2070 mean break-up dates.

focusing over the Arctic islands as well as northern Quebec and southern Baffin Island rather than the Alaskan coast (as seen in scenario 1). Similar to break-up and freeze-up, the ICD differences for the two CRCM scenarios (Fig. 12c) is mainly \pm 5 days, with more areas in the 5-10 day differences from the combined effect of break-up and freeze-up differences.

Both future scenarios show a loss of perennial ice cover as well as large reductions to the area where occasional summer ice cover is predicted to occur (Fig. 13). There is a larger reduction of grid cells where occasional summer ice occurs with the no-snow scenarios than with snow. However, a smaller area remains with occasional summer ice when snow is taken into account, reflecting the insulating effects of the snow, leading to thinner ice, leading to fewer summers where any ice persists in the lakes. Using the $10 \mathrm{~m}$ hypothetical lakes as an example, a reduction of 192 grid cells where perennial or occasional ice would occur $\left(388800 \mathrm{~km}^{2}\right)$ was seen with no-snow and reduction of 91 grid cells $\left(184275 \mathrm{~km}^{2}\right)$ was seen with snow. Also, while scenario 2 begins with slightly more occasional summer ice, due to the greater warming in the high latitude areas by the 2041-2070 mean in this scenario, a greater reduction in the summer ice cover is seen.

\subsubsection{Ice cover thickness 2041-2070}

Along with a reduction in the ICD for the future scenarios, the mean maximum thickness of the ice cover on the lakes is also shown to decrease. Scenario 1, for the snow-free simulations, has an average of $32 \mathrm{~cm}$ less ice, ranging from 20 $40 \mathrm{~cm}$ with up to $60 \mathrm{~cm}$ reduction in thickness in the northwest Alaskan coastal regions. The snow covered simulations show most of the region to have a loss of thickness ranging from $10-30 \mathrm{~cm}$, with a few small regions reaching just over $40 \mathrm{~cm}$ reduction (average of $25 \mathrm{~cm}$ reduction in ice thickness). Spatially, the snow cover scenarios produce quite different results (Fig. 14a, b). With the snow-free simulations, the deeper the lake, the more change in thickness predicted ( $30 \mathrm{~m}$ lakes mainly greater than $30 \mathrm{~cm}$ reduction in ice thickness). With snow added on top of the ice cover however, the $10 \mathrm{~m}$ deep lakes show slightly less loss of thickness than the $3 \mathrm{~m}$ lakes, with the most change occurring in the $30 \mathrm{~m}$ lakes.

Scenario 2, being generally cooler than scenario 1 for the majority of the study area shows less predicted loss of thickness, with $21 \mathrm{~cm}$ less (mean) for snow covered and $24 \mathrm{~cm}$ less for snow free. Again the deeper the lake, the more change in thickness seen, but less change than scenario 1 . In this case, most of the changes to the ice thicknesses are in the 
b) Scenario 2
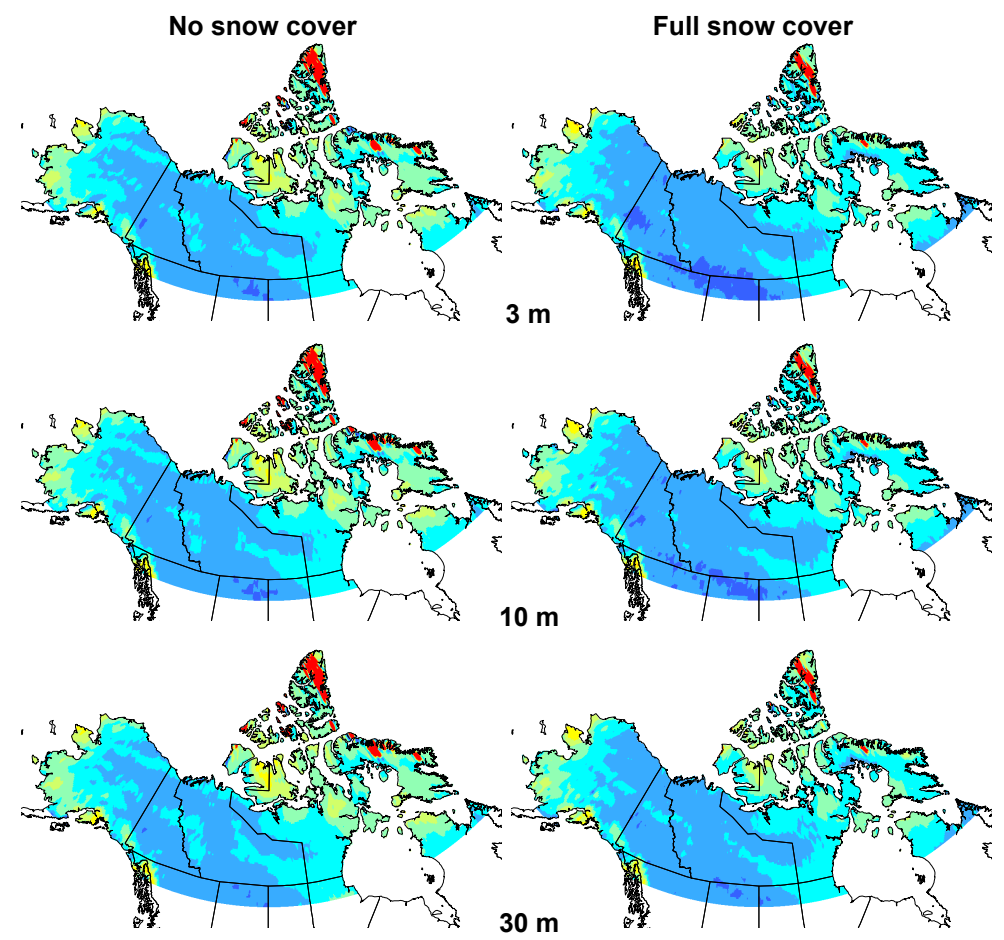

Change in mean break-up date (days earlier), 1961-1990 mean to 2041-2070 mean

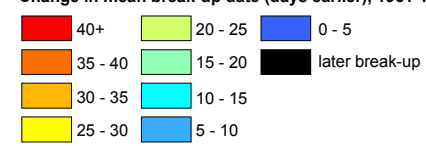

Fig. 10b. Continued.

c) Scenario differences

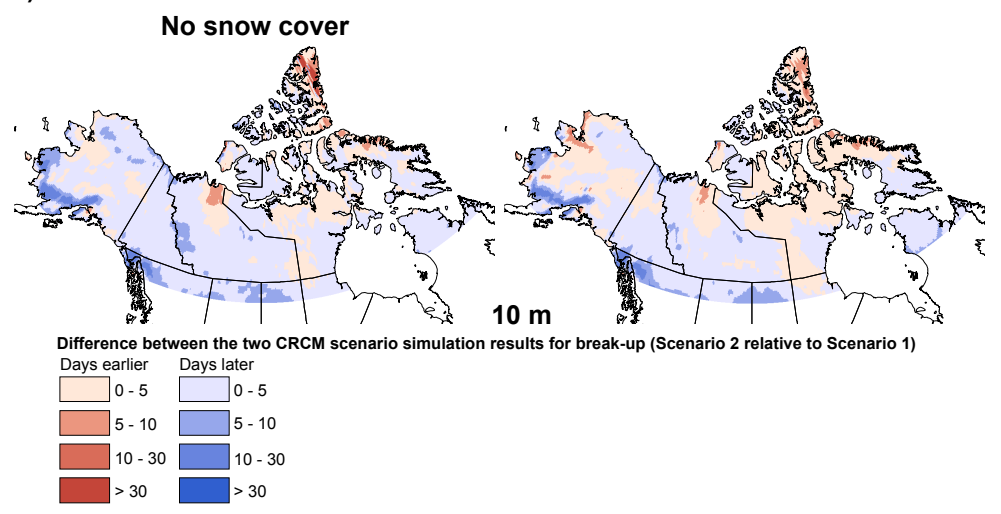

Fig. 10c. Continued.

10-30 cm, except for some areas of the CAA and northern Quebec/southern Baffin Island where this increases to 30$40 \mathrm{~cm}$.

Comparing the two scenarios (Fig. 14c), most of the area has less than $10 \mathrm{~cm}$ difference between them, with the exception of the northern western Alaskan coastal areas in the same areas the differences in ICD were seen. With snow covered scenarios the difference is less than $20 \mathrm{~cm}$ (with scenario 2 being thicker) however with the snow free scenarios this difference increased to up to $25 \mathrm{~cm}$. 


\section{a) Scenario 1}
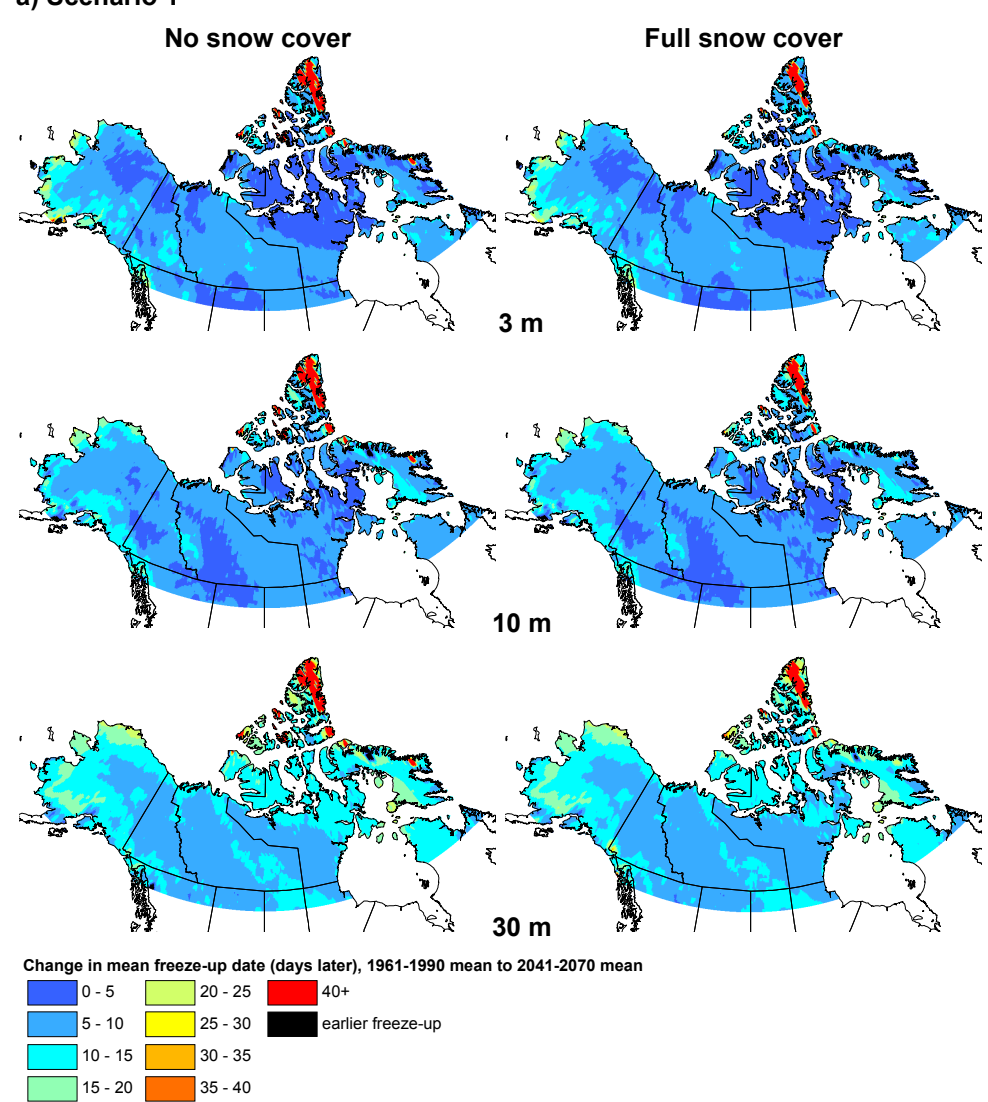

Fig. 11a. Change in mean freeze-up date from 1961-1990 to 2041-2070 for (a) scenario 1; (b) scenario 2; (c) the difference between the scenarios for the 2041-2070 mean freeze -up dates.

Mean maximum thickness amounts include both snow ice and black ice in the total amounts. Looking at the changes in to the snow ratio ice from 1961-1990 to 2041-2070 most of the study area experiences some increase, though in the central regions this increase is less than $1 \%$ (Fig. 15). Also, with the shallower lakes, increased snow ice ratios are seen around Hudson Bay and up into the High Arctic that are not evident with the deeper $30 \mathrm{~m}$ lakes. Areas of decreased snow ice ratio are along the warmer coastal areas of Alaska (and a small area of northern Quebec/Labrador), corresponding to areas of decreased SWE (Fig. 9b) where increased amounts of precipitation would be expected to fall as rain rather than snow, reducing the chance for snow to accumulate on the ice surface to form snow ice.

\section{Summary and conclusions}

Ice phenology simulations using the lake ice model CLIMo driven by climate model output from CRCM scenarios for 1961-1990 had an average absolute error of less than 1 week compared to observation data at 15 validation sites across northern Canada. For three validation lakes where CLIMo was able to represent the phenology well, the mean maximum ice thickness had an average absolute error of $12 \mathrm{~cm}$ $(6.5 \%)$ compared to the measured ice thickness. Capturing the correct ice thickness in the simulations depends on how well the snow cover on the ice surface is represented both in terms of depth and density.

By 2041-2070, the mean break-up date was shown to shift 7 days earlier with snow cover on the lakes and 14 days earlier with no snow cover. Most of the northern areas show a change in the range of 10-25 days earlier for break-up (excluding the areas of maximum change discussed later). Mean freeze-up for the north was shown to shift 7, 8 and 11 days later (3, 10 and $30 \mathrm{~m}$ depths respectively) with shifts ranging from 0-15 days later, a smaller change than seen in break-up. These ranges are comparable to those identified by Dibike et al. (2011), using the MyLake model (Saloranta and Anderson, 2007) to examine future changes over a broader and more southern area of North America. Ice cover durations ranged from 10 to more than 40 days shorter, with the areas of greatest change in scenario 1 located near the Alaskan coast, the far northern Arctic islands, and northern Quebec; while scenario 2 had the greatest changes in the north eastern 
b) Scenario 2
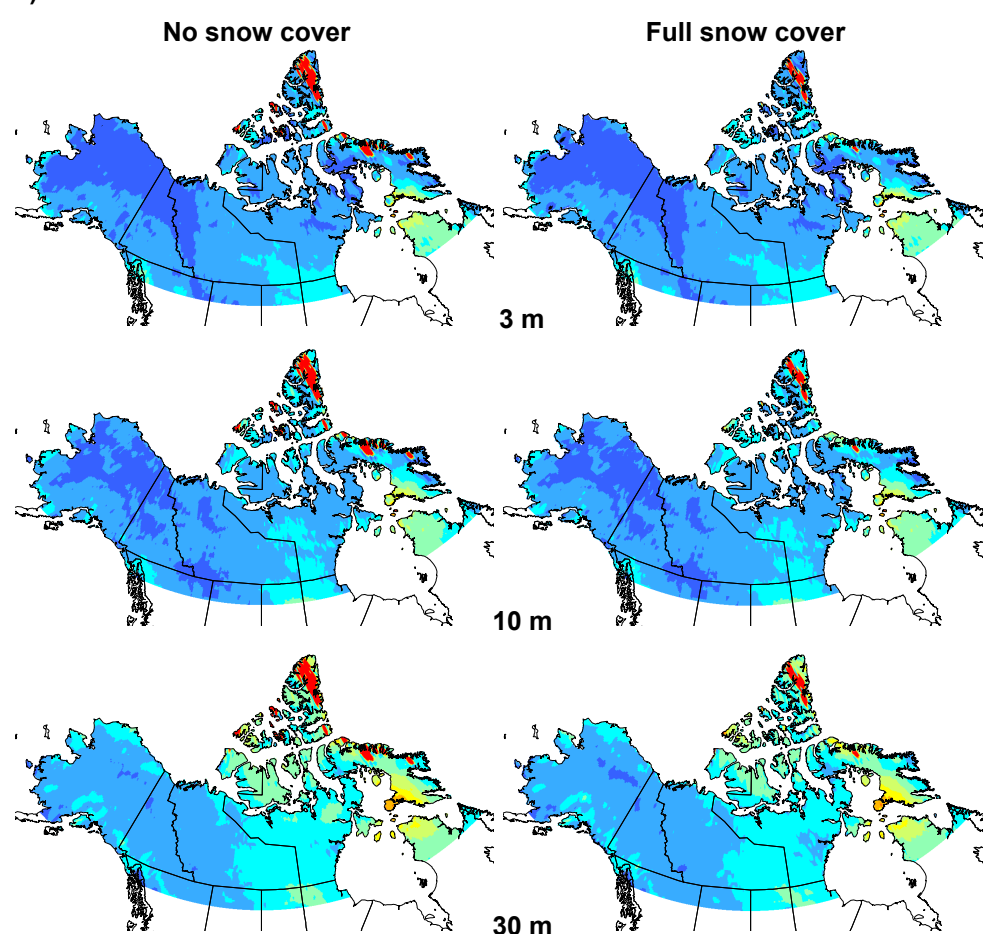

Change in mean freeze-up date (days later), 1961-1990 mean to 2041-2070 mean

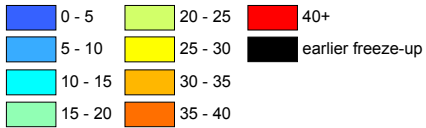

Fig. 11b. Continued.

c) Scenario differences

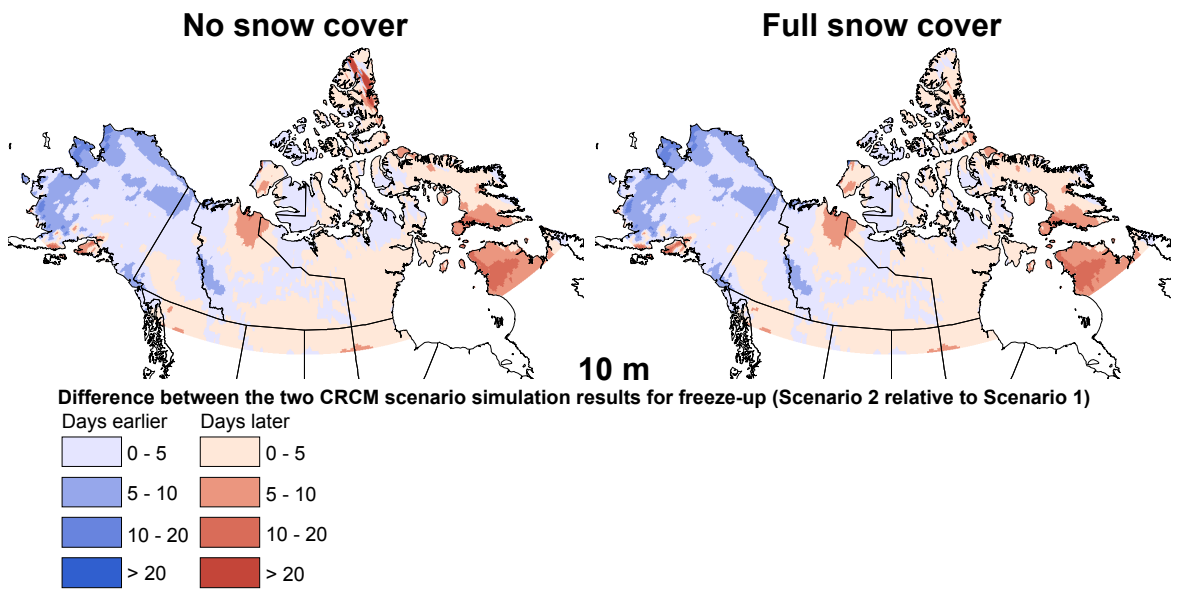

Fig. 11c. Continued. 


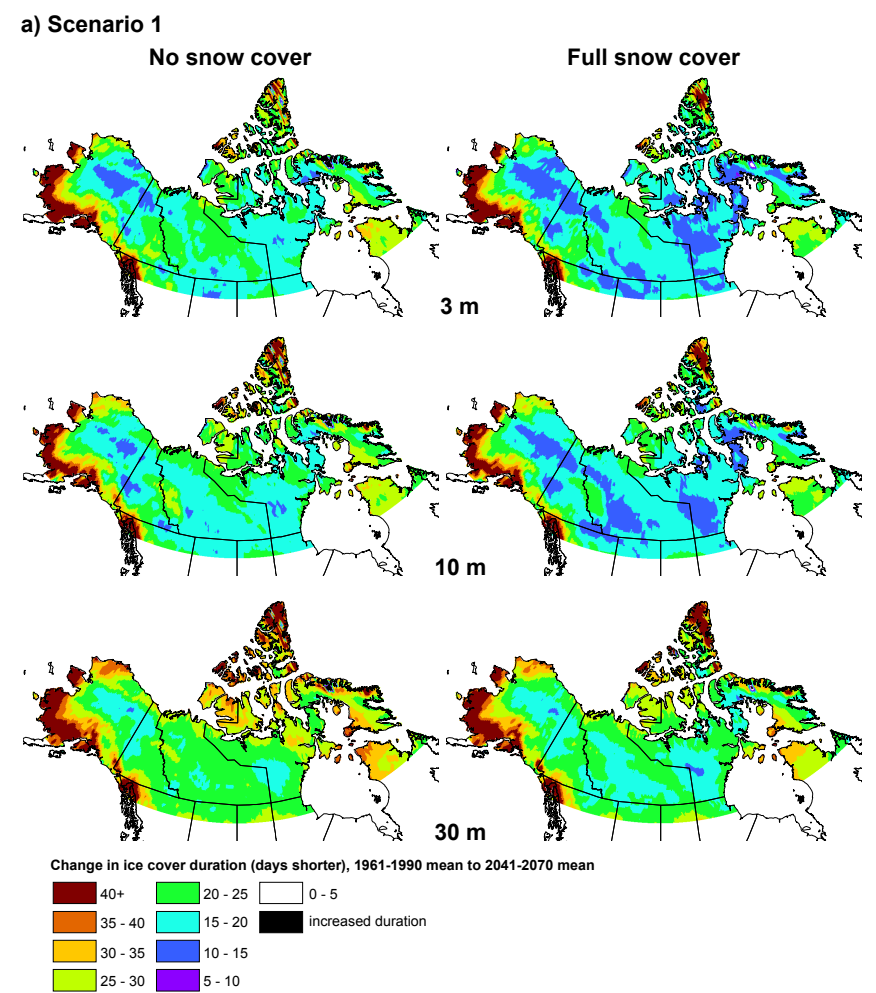

Fig. 12a. Change in mean ice cover duration from 1961-1990 to 2041-2070 for (a) scenario 1; (b) scenario 2; (c) the difference between the scenarios for the 2041-2070 mean ice cover duration.

\section{b) Scenario 2}
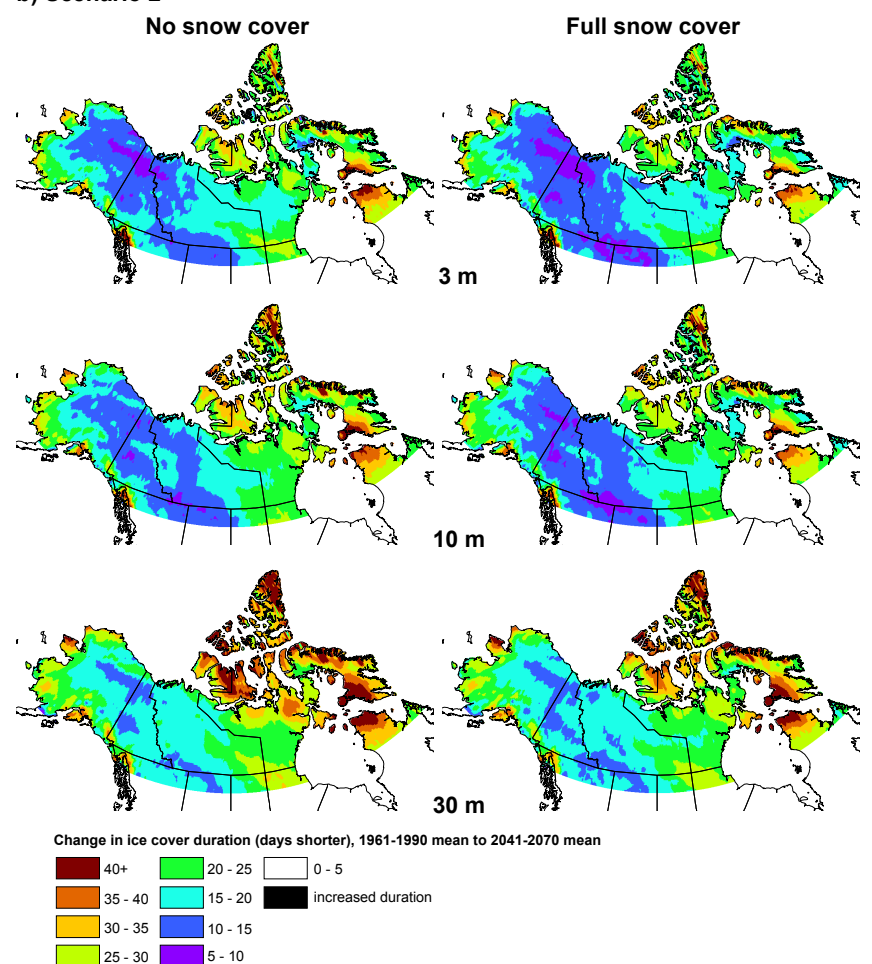

Fig. 12b. Continued. 
c) Scenario differences

No snow cover

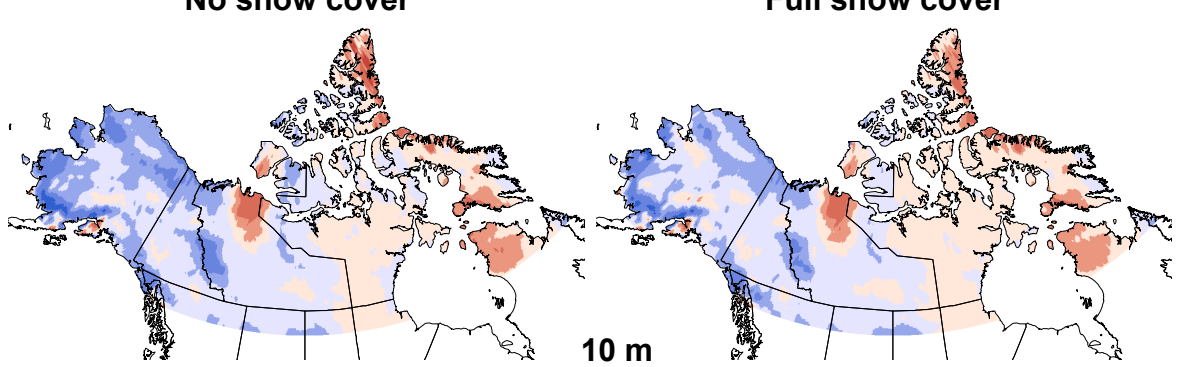

Difference between the two CRCM scenario simulation results for ICD (Scenario 2 relative to Scenario 1)

Days shorter Days longer

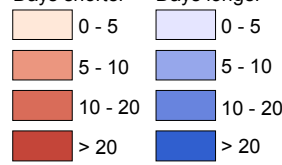

Fig. 12c. Continued.
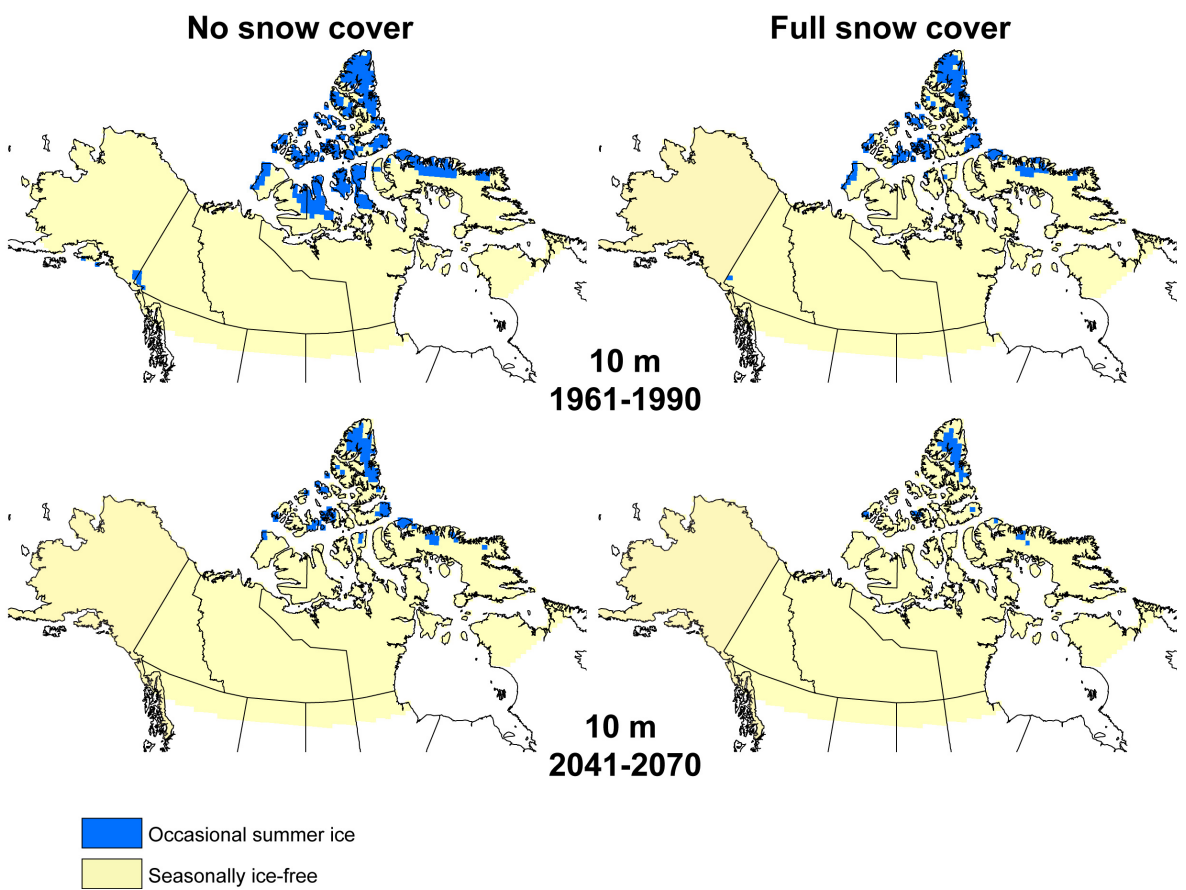

Fig. 13. Area of occasional summer ice (including perennial ice cover) and the change from 1961-1990 to 2041-2070. Scenario 1, 10 m lakes shown. 


\section{a) Scenario 1}
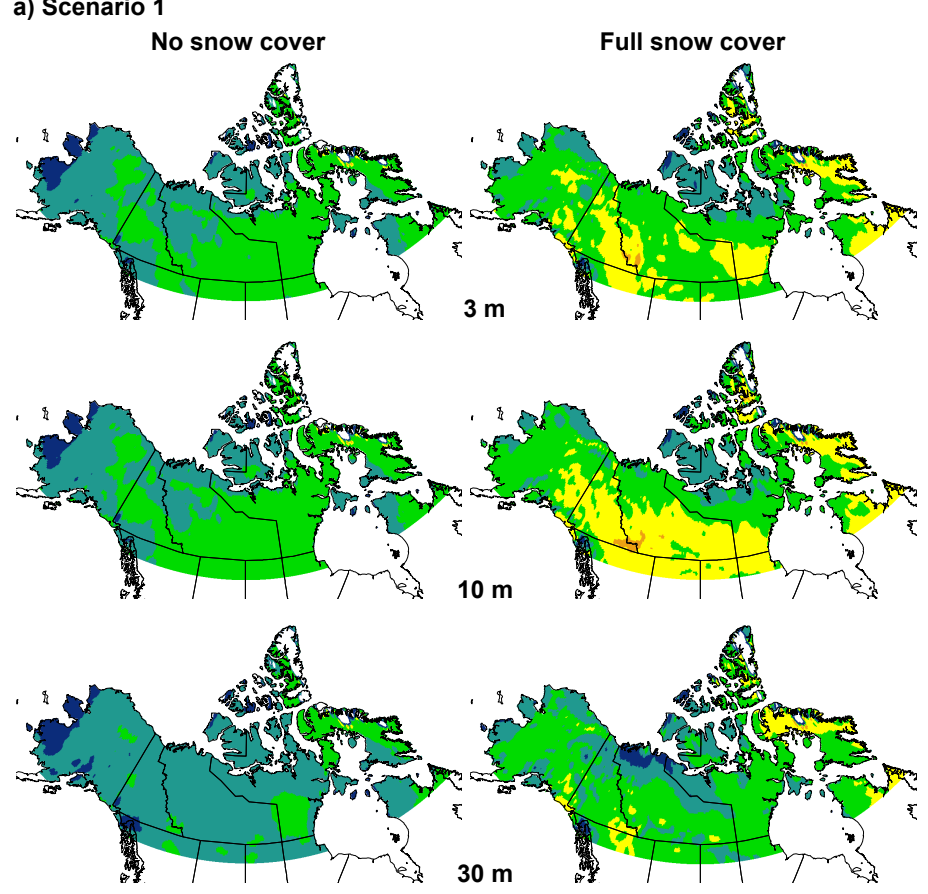

Change in mean maximum thickness (cm), 1961-1990 mean to 2041-2070 mean

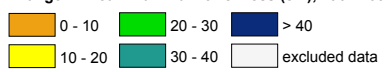

Fig. 14a. Change in mean maximum thickness 1961-1990 to 2041-2070 for (a) scenario 1; (b) scenario 2; (c) the difference between the scenarios for the 2041-2070 mean maximum thickness.

b) Scenario 2
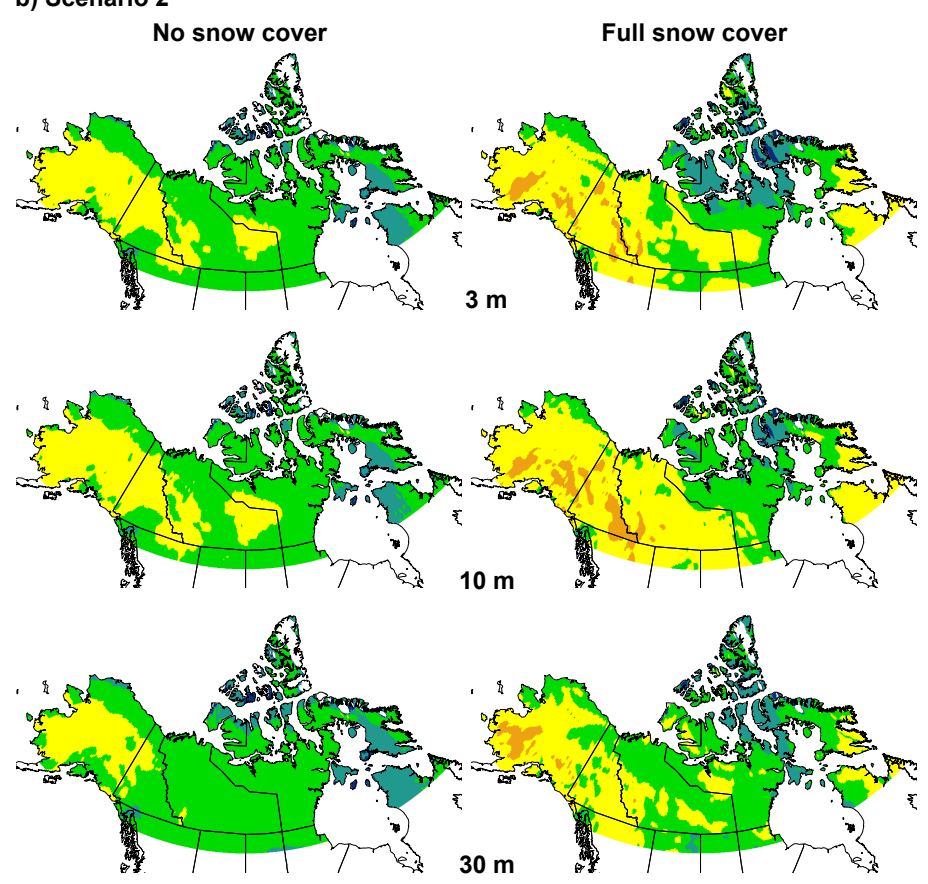

Change in mean maximum thickness (cm), 1961-1990 mean to 2041-2070 mean

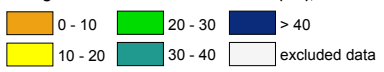

Fig. 14b. Continued. 


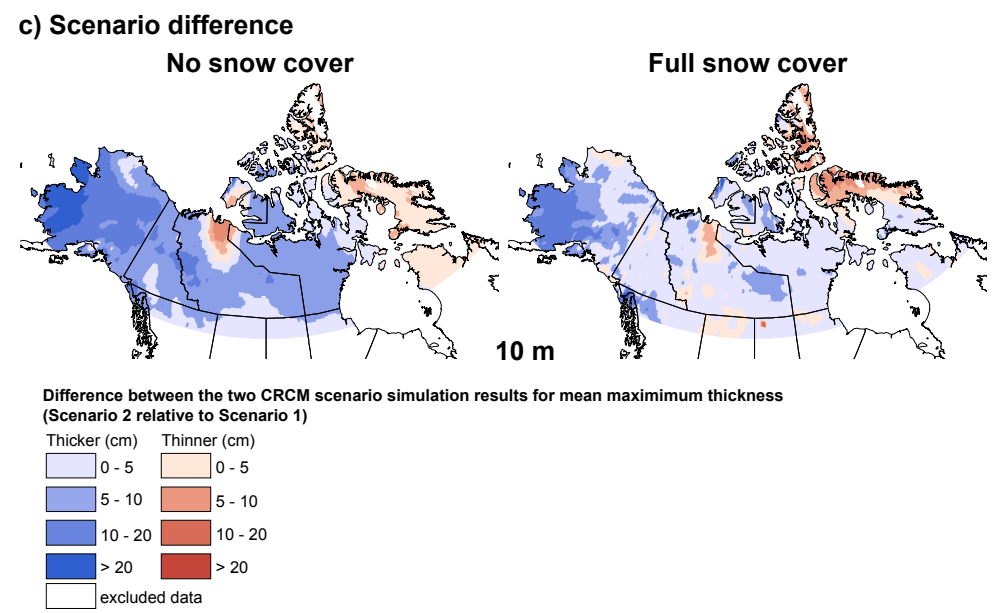

Fig. 14c. Continued.
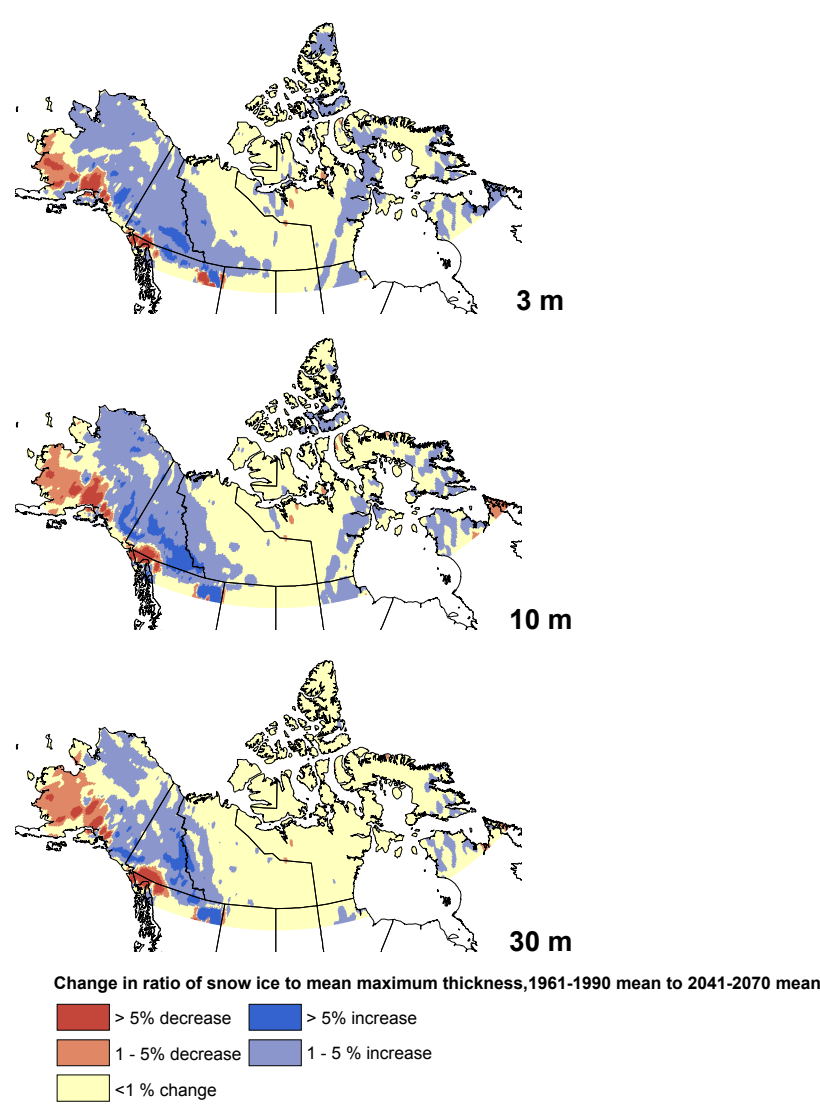

Fig. 15. Change in snow ice thickness to total ice thickness from 1961-1990 to 2041-2070 mean.

section of the study area (the CAA and southern Baffin Island/northern Quebec). In the remainder of the study area (away from the areas of maximum change) the shallower lakes ( 3 and $10 \mathrm{~m}$ ) show mainly 10-25 days shorter ICD (5-
25 days shorter for scenario 2), while the $30 \mathrm{~m}$ lakes show primarily 15-30 days shorter ICD (10-30 days shorter for scenario 2). The areas of maximum change identified in this study were more extreme than those in the results produced by Dibike et al. (2011) for reduction in ICD, however the spatial patterns in their results were most similar to scenario 1 .

Both scenarios show a drastic reduction in the number of grid cells with perennial ice cover, with none remaining in scenario 2. The areas of occasional summer ice cover are also reduced, with greater losses when no snow cover is on the ice (though a smaller area remains when snow cover is taken into account).

Changes to the mean maximum thickness show an average of $25 \mathrm{~cm}$ less ice for the snow simulations $(21 \mathrm{~cm}$ less for scenario 2), and $32 \mathrm{~cm}(24 \mathrm{~cm})$ less ice for the snow-free simulations. Overall, scenario 1 shows more reduction in ice thickness than scenario 2 with the maximum loss reaching over $40 \mathrm{~cm}$ in the Alaskan coast areas (scenario 1) and up to $40 \mathrm{~cm}$ reduction in the CAA and northern Quebec/southern Baffin Island (scenario 2). The ratio of snow ice to total maximum ice thickness was also shown to increase throughout the study area, with the exception of the Alaskan coastal areas, where a reduction in the SWE was also observed. Dibike et al. (2011) show the area with the thickness changes along the northern coast lines at the upper extent of their study area (up to $25 \mathrm{~cm}$ reduction), which is again, most comparable to the full snow simulations in scenario 1 .

The use of two variations of the CRCM data allows for some measure of uncertainty in the range of dates produced by the simulations. Break-up and freeze-up dates were generally within 5 days for the two scenarios, except in three key areas where the most variability is seen throughout, around the coasts in: Alaska, the far north on Ellesmere Island and northern Quebec/southern Baffin Island (and to a lesser extent a localised area on the coast of the NWT). In these areas, 
differences between the scenarios for freeze-up range up to \pm 16 days (the very large values ranging up to $\sim 100$ days in the far north are due to the different amounts of perennial ice cover). Thickness typically varied less than $10 \mathrm{~cm}$ between the scenarios except for Alaska, where the snow free simulations were up to $20 \mathrm{~cm}$ different (snow covered up to $25 \mathrm{~cm}$ ) in the same areas of maximum differences seen in ICD. The variations in these areas are a reflection of the different patterns of temperature change between the scenarios by the time they evolve to 2041-2070. Scenario 1 shows the greatest warming over the Alaska region in the fall and winter, while scenario 2 has the greatest warming in the Quebec/Baffin region in the winter and the CAA in the fall. Higher temperatures throughout in the spring for scenario 1 would affect the break-up, and the warmer winter temperatures would lead to less ice thickening and earlier spring break-up.

Changes to northern lakes as a result of a shorter ice cover season and thinner ice covers could lead to in an increase to the availability of under ice habitat, a prolonged productivity period (ACIA, 2005) and a change to the habitats and species from increased amounts of light and UV radiation reaching the water (e.g. Reist et al., 2006). Longer open water seasons will result in changes to the stratification and circulation patterns in the lakes (ACIA, 2005), and previously stratified perennially ice covered lakes that have changed to seasonally ice free will experience wind-driven mixing, changing the water column regime (Mueller et al., 2009). Longer open water seasons will also lead to increased evaporation from lakes, and while ponds in the High Arctic are drying out as the climate warms (Smol and Douglas, 2007) the shrinking/drying of lakes and ponds will likely be mitigated in some areas by increases in precipitation (Duguay et al., 2009). A shortened ice covered season is also expected to have a detrimental effect on the duration and stability of the winter ice roads in northern Canada and Alaska. By mid-century, Canada is predicted to lose access to $13 \%$ of the northern areas currently accessible via ice roads, while Alaska is predicted to lose access to $29 \%$, with most of the changes occurring in April and November (Stephenson et al., 2011).

Reanalysis data or climate model output specifically created for the arctic regions could be beneficial for future predictions. Alternatively, the use of model ensemble data for future ice cover simulations could be beneficial as the largest source of uncertainty can come from the section of the model used (e.g. Prudhomme and Davis, 2009). Downscaling projects to examine regional changes to the future climate are underway through programs such as CORDEX: (COordinated Regional climate Downscaling Experiment, regional climate change scenarios) and high resolution climate change scenarios are being studied at NARCCAP (North American Regional Climate Change Assessment Program) to better assess the uncertainties in the various model simulations.

The gridded phenology maps produced herein highlight the important effects that both snow cover and lake depth have on lake ice regimes, and that snow cover tends to mitigate the changes to the ice cover. As well, the use of the two scenarios suggests areas of the greatest uncertainty in the phenology and thickness changes, primarily the Alaska coastal areas, the eastern CAA and the Baffin Island/northern Quebec region.

Acknowledgements. This research was supported by a NSERC postgraduate scholarship (CGS) to L. Brown and Discovery Grant to C. Duguay. The CRCM data was generated and supplied by Ouranos. We are indebted to Ross Brown (Environment Canada at OURANOS) for valuable advice throughout the project.

Edited by: S. Marshall

\section{References}

ACIA: Arctic Climate Impact Assessment: Cambridge University Press, New York, 1042 pp., 2005.

Anderson, W. L., Robertson, D. M., and Magnuson, J. J.: Evidence of climatic change and projected future change, Limnol. Oceanogr., 41, 815-821,1996.

Beljaars, A. C. M., Holtslag, A. A. M., and van Westrhenen, R. M.: Description of a software library for the calculation of surface fluxes. KNMI Technical Report; TR-112, Royal Netherlands Meteorological Institute (KNMI), Netherlands, 1989.

Beltaos, S., Prowse, T., Bonsal, B., MacKay, R., Romolo, L., Pietroniro, A., and Toth, B.: Climatic effects on ice-jam flooding of the Peace-Athabasca Delta, Hydrol. Process., 20, 4031-4050, doi:10.1002/hyp.6418, 2006.

Blenckner, T., Jarvinen, M., and Weyhenmeyer, G. A.: Atmospheric circulation and its impact on ice phenology in Scandinavia, Boreal Environ. Res., 9,371-380, 2004.

Bonsal, B. R. and Kochtubajda, B.: An assessment of present and future climate in the Mackenzie Delta and the near-shore Beaufort Sea region of Canada, Int. J. Climatol. 29, 1780-1795, doi:10.1002/joc.1812, 2009.

Brown, L. C. and Duguay, C. R.: The response and role of ice cover in lake-climate interactions. Prog. Phys. Geog., 34, 671704, doi:10.1177/0309133310375653, 2010.

Brown, L. C. and Duguay, C. R.: A comparison of simulated and measured lake ice thickness using a Shallow Water Ice Profiler, Hydrol. Process., 25, 2932-2941, doi:10.1002/hyp.8087, 2011.

Brown, R. D. and Braaten, R. O.: Spatial and temporal variability of Canadian monthly snow depths, 1946-1995, Atmos. Ocean, 36, 37-45, 1998.

Brown, R. D. and Mote, P.: The response of Northern Hemisphere snow cover to a changing climate, J. Climate, 22, 2124-2145, 2009.

Brown, R., Derksen, C., and Wang, L.: A multi-data set analysis of variability and change in Arctic spring snow cover extent, 1967-2008, J. Geophys. Res., 115, D16111, doi:10.1029/2010JD013975, 2010.

Canadian Ice Thickness Program: available at: http://www.ec.gc. ca/glaces-ice/default.asp?lang=En $\backslash \& n=E 1 B 3129 D-1,2010$.

Caya, D. and Laprise, R.: A semi-Lagrangian semi-implicit regional climate model: the Canadian RCM, Mon. Weather Rev., 127, 341-362, 1999. 
Chung, Y. C., Belair, S., and Mailhot, J.: Simulation of Snow on Arctic Sea Ice Using a Coupled Snow-Ice Model, J. Hydrometeor., 11, 199-210, 2010.

Dibike, Y., Prowse, T., Bonsal, B., de Rham, L., and Saloranta, T.: Simulation of North American lake-ice cover characteristics under contemporary and future climate conditions, Int. J. Climatol., 31, doi:10.1002/joc.2300, 2011.

Douglas, M. S. V. and Smol, J. P.: Freshwater diatoms as indicators of environmental change in the High Arctic, in: The Diatoms: Applications for the Environmental and Earth Sciences, edited by: Stoermer, E. F. and Smol, J. P., Cambridge University Press, Cambridge, 227-244, 1999.

Duguay, C. R., Flato, G. M., Jeffries, M. O., Ménard, P., Morris, K., and Rouse, W. R.: Ice-cover variability on shallow lakes at high latitudes: model simulations and observations, Hydrol. Process., 17, 3465-3483, 2003.

Duguay, C. R., Prowse, T. D., Bonsal, B. R., Brown, R. D., Lacroix, M. P., and Ménard, P.: Recent trends in Canadian lake ice cover, Hydrol. Process., 20, 781-801, 2006.

Duguay, C. R., Pivot, F. C., Brown, R. D., and Flato, G. M.: Continental-scale simulation of lake ice cover phenology, thickness and composition in Canada. CMOS-CGU-AMS Congress. St. Johns, Newfoundland, Canada, May 28-June 1, 2007, Abstract ID: 1908, 2007.

Duguay, C. R., Macrae, M. L., Parrott, J. A., Brown, L. C., and Svacina, N.: Response of shallow lakes and ponds to contemporary climate change in the Hudson Bay Lowland near Churchill, Manitoba, American Geophysical Union Fall Meeting, San Francisco, California, USA, December 14-18, 2009, C42A-03, 2009.

Dyck, M. G.: Community monitoring of environmental change: College-based limnological studies at Crazy Lake (Tasirluk), Nunavut, Arctic, 60, 55-61, 2007.

Flato, G. M. and Brown, R. D.: Variability and climate sensitivity of landfast Arctic sea ice, J. Geophys. Res., 101, 25767-25777, 1996.

Gao, S. and Stefan, H. G.: Potential climate change effects on ice covers of five freshwater lakes, J. Hydrol. Eng., 9, 226-234, 2004.

Gagnon, P., Konan, B., Rousseau, A. N., and Slivitzky, M.: Hydrometeorological validation of a Canadian Regional Climate Model simulation within the Chaudière and Châteauguay watersheds (Québec, Canada), Can. J. Civ. Eng., 36, 253-266, 2009.

Hinzman, L. D., Bettez, N. D., Bolton, W. R., Chapin, F. S., Dyurgerov, M. B., Fastie, C. L., Griffith, B., Hollister, R. D., Hope, A., Huntington, H. P., Jensen, A. M., Jia, G. J., Jorgenson, T., Kane, D. L., Klein, D. R., Kofinas, G., Lynch, A. H., Lloyd, A. H., McGuire, A. D., Nelson, F. E., Oechel, W. C., Osterkamp, T. E., Racine, C. H., Romanovsky, V. E., Stone, R. S., Stow, D. A., Sturm, M., Tweedie, C. E., Vourlitis, G. L., Walker, M. D., Walker, D. A., Webber, P. J., Welker, J. M., Winker, K. S., and Yoshikawa, K.: Evidence and implications of recent climate change in northern Alaska and other Arctic regions, Clim. Change, 72, 251-298, 2005.

Holland, M. M., Bitz, C. M., and Tremblay, B: Future abrupt reductions in the summer Arctic sea ice, Geophys. Res. Lett., 33, L23503, doi:10.1029/2006GL028024, 2006

IPCC, 2007. Chapter 10 supplementary figures: http://www. ipcc.ch/publications_ and _data/ar4/wg1/en/en/chapter10/Ch10_ indiv-maps.html, 2011.
Jeffries, M. O., Morris, K., and Duguay, C. R.: Lake ice growth and decay in central Alaska, USA: observations and computer simulations compared, Ann. Glaciol., 40, 1-5, 2005.

Jensen, O. P., Benson, B. J., Magnuson, J. J., Card, V. M., Futter, M. N., and Soranno, P. A.: Spatial analysis of ice phenology trends across the Laurentian Great Lakes region during a recent warming period, Limnol. Oceanogr., 52, 2013-2026, 2007.

Johnson, S. L. and Stefan, H. G.: Indicators of climate warming in Minnesota: Lake ice covers and snowmelt run off, Climatic Change, 75, 421-453, 2006.

Kaufman, D. S., Schneider, D. P., McKay, N. P., Ammann, C. M., Bradley, R. S., Briffa, K. R., Miller, G. H., Otto-Bliesner, B. L., Overpeck, J. T., and Vinther, B. M.: Arctic Lakes 2k Project Members: Recent Warming Reverses Long-Term Arctic Cooling, Science, 325, 1236, doi:10.1126/science.1173983, 2009.

Keatley, B. E., Douglas, M. S. V., and Smol, J. P.: Prolonged ice cover dampens diatom community response to recent change in high arctic lakes, Arct. Antarct. Alp. Res., 40, 364-372, 2008.

Kheyrollah Pour, H., Duguay, C. R. , Martynov, A., and Brown, L. C.,: Simulation of surface temperature and ice cover of large northern lakes with 1-D models: A comparison with MODIS satellite data and in situ measurements, Tellus Series A: Dynamic Meteorology and Oceanography, in review, 2011.

Korhonen, J.: Long-term changes in lake ice cover in Finland, Nord. Hydrol., 4-5, 347-363, 2006.

Kvambekk, A. S. and Melvold, K.: Long-term trends in water temperature and ice cover in the subalpine lake, Øvre Heimdalsvatn, and nearby lakes and rivers, Hydrobiologia, 642, 47-60, doi:10.1007/s10750-010-0158-2, 2010.

Laprise, R.: Regional climate modeling, J. Comput. Phys., 227, 3641-3666, 2008.

Latifovic, R. and Pouliot, D.: Analysis of climate change impacts on lake ice phenology in Canada using the historical satellite data record, Remote Sens. Environ., 106, 492-507, 2007.

Lenormand, F., Duguay, C. R., and Gauthier, R.: Development of a historical ice database for the study of climate change in Canada, Hydrol. Process., 16, 3707-3722, 2002.

Livingstone, D. M. and Adrian R.: Modeling the duration of intermittent ice cover on a lake for climate change studies, Limnol. Oceanogr., 54, 1709-1722, 2009.

Magnuson, J. J., Robertson, D. M., Benson, B. J., Wynne, R. H., Livingstone, D. M., Arai, T., Assel, R. A., Barry, R. G., Virginia Card, V., Kuusisto, E., Granin, N. G., Prowse, T. D., Stewart, K. M., and Vuglinski, V. S.: Historical trends in lake and river ice cover in the Northern Hemisphere, Science, 289, 1743-1746, 2000, errata, Science, 291, 254, 2001.

Maykut, G. A. and Untersteiner, N.: Some results form a timedependant thermodynamic model of sea ice, J. Geophys. Res., 76, 1550-1-575, 1971.

Meehl, G. A., Stocker, T. F., Collins, W. D., Friedlingstein, P., Gaye, A. T., Gregory, J. M., Kitoh, A., Knutti, R., Murphy, J. M., Noda, A., Raper, S. C. B., Watterson, I. G., Weaver, A. J., and Zhao, Z.-C.: Global Climate Projections, in: Climate Change 2007: The Physical Science Basis. Contribution of Working Group I to the Fourth Assessment Report of the Intergovernmental Panel on Climate Change, edited by: Solomon, S., Qin, D., Manning, M., Chen, Z., Marquis, M., Averyt, K. B., Tignor, M., and Miller, H. L., Cambridge University Press: Cambridge, United Kingdom and New York, NY, USA, 2007. 
MSC: Canadian Snow Data CD-ROM, CRYSYS Project, Climate Processes and Earth Observation Division, Meteorological Service of Canada, Downsview, Ontario, January, 2000.

Ménard, P., Duguay, C. R., Flato, G. M., and Rouse, W. R.: Simulation of ice phenology on Great Slave Lake, Northwest Territories, Canada, Hydrol. Process., 16, 3691-3706, 2002.

Ménard, P., Duguay, C. R., Pivot, F. C., Flato, G. M., and Rouse, W. R.: Sensitivity of Great Slave Lake ice cover to climate variability and climatic change, in: Proceedings of the 16th International Symposium on Ice, Dunedin, New Zealand, 2-6 December 2002, Volume 3, 57-63, 2003.

Mironov, D.: Parameterization of lakes in numerical weather prediction, Part 1: Description of a lake model, Offenbach: Consortium for Small-scale Modeling, Technical Report 11, Deutscher Wetterdienst, Offenbach am Main, Germany, 41 pp., 2008.

Music, B. and Caya, D.: Evaluation of the Hydrological Cycle over the Mississippi River Basin as Simulated by the Canadian Regional Climate Model (CRCM), J. Hydrometeorol., 8, 969-988, 2007.

Mueller, D. R., Van Hove, P., Antoniades, D., Jeffries, M. O., and Vincent, W. F.: High Arctic lakes as sentinel ecosystems: Cascading regime shifts in climate, ice cover, and mixing, Limnol. Oceanogr., 54, 2371-2385, 2009.

Morris, K., Jeffries, M., and Duguay, C.: Model simulation of the effects of climate variability and change on lake ice in central Alaska, USA, Ann. Glaciol., 40, 113-118, 2005.

North American Regional Climate Change Assessment Program: http://www.narccap.ucar.edu/results/crcm-cgcm3-results. html, 2011.

Palecki, M. A. and Barry, R. G.: Freeze-up and break-up of lakes as an index of temperature changes during the transition seasons: a case study for Finland, J. Appl Meteorol., 25, 893-902, 1986.

Peters, D. L. and Buttle, J. M.: The effects of flow regulation and climatic variability on obstructed drainage and reverse flow contribution in a northern river-lake-delta complex, Mackenzie Basin headwaters, River Res. Applic., 26, 1065-1089, 2010.

Plummer, D. A., Caya, D., Frigon, A., Côté, H., Giguère, M., Paquin, D., Biner, S., Harvey, R., and De Elia, R.: Climate and climate change over North America as simulated by the Canadian RCM, J. Climate, 19, 3112-3132, 2006.

Pohl, S., Marsh, P., and Bonsal, B. R.: Modeling the Impact of Climate Change on Runoff and Annual Water Balance of an Arctic Headwater Basin, Arctic, 60, 173-186, 2007.

Prowse, T. D. and Beltaos, S.: Climatic control of river-ice hydrology: a review, Hydrol. Process., 16, 805-822, 2002.

Prowse, T. D., Bonsal, B. R., Duguay, C. R., and Lacroix, M. P.: River-ice break-up/freeze-up: a review of climatic drivers, historical trends and future predictions, Ann. Glaciol., 46, 443-451, 2007.

Prudhomme, C. and Davies, H.: Assessing uncertainties in climate change impact analyses on the river flow regimes in the UK, Part 2: future climate, Climatic Change, 93, 197-222, 2009.

Räisänen, J.: Warmer climate: less or more snow?, Clim. Dynam., 30, 307-319, doi:10.1007/s00382-007-0289-y, 2007.

Reist, J. D., Wrona, F. J., Prowse, T. D., Dempson, J. B., Power, M., Köck, G., Carmichael, T. J., Sawatzky, C. D., Lehtonen, H., and Tallman, R. F.: Effects of Climate Change and UV Radiation on Fisheries for Arctic Freshwater and Anadromous Species, Ambio, 35, 402-410, doi:10.1579/0044-7447, 2006.
Rouse, W. R., Binyamin, J., Blanken, P. D., Bussières, N., Duguay, C. R., Oswald, C. J., Schertzer, W. M., and Spence, C.: The influence of lakes on the regional energy and water balance of the central Mackenzie, Chapter 18 in: Cold Region Atmospheric and Hydrologic Studies: The Mackenzie GEWEX Experience, Vol. 1, edited by: Woo, M. K., Springer-Verlag: Berlin, 309325, 2008.

Saloranta, T. M. and Anderson, T.: MyLake - A multi-year lake simulation model code suitable for uncertainty and sensitivity analysis simulations, Ecol. Model., 207, 45-60, 2007.

Samuelsson, P., Kourzeneva, E., and Mironov, D.: The impact of lakes on the European climate as simulated by a regional climate model, Boreal Environ. Res., 15, 113-129, 2010.

Smol, J. P.: Paleophycology of a High Arctic lake near Cape Herschel, Ellesmere Island, Can. J. Botany, 61, 2195-2204, 1983.

Smol, J. P.: Paleoclimate proxy data from freshwater, Arctic diatoms. Verh. Int. Ver. Theor. Angew. Limnol., 23, 837-844, 1988.

Smol, J. P. and Douglas, M. S. V.: Crossing the final ecological threshold in high Arctic ponds, P. Natl. Acad. Sci. USA, 104, 12395-12397, 2007.

Smol, J. P., Wolfe, A. P., Birks, H. H., Douglas, M. S. V., Jones, V., Korhola, A., Pienitz, R., Rühland, K., Sorvari, S., Antoniades, D., Brooks, S. J., Fallu, M. A., Hughes, M., Keatley, B. E., Laing, T. E., Michelutti, N., Nazarova, L., Nyman, M. Paterson, A. M., Perren, B., Quinlan, R., Rautio, M., Saulnier-Talbot, E., Susanna Siitonen, S., Solovieva, N., and Weckström, J.: Climate-driven regime shifts in the biological communities of Arctic lakes, $\mathrm{P}$. Natl. Acad. Sci. USA, 102, 4397-4402, 2005.

Stephenson, S. R., Smith, L. C., and Agnew, J. A.: Divergent longterm trajectories of human access to the Arctic, Nature Climate Change, 1, 156-160, doi:10.1038/NCLIMATE1120, 2011.

Sturm, M. and Liston, G. E.: The snow cover on lakes of the Arctic Coastal Plain of Alaska, USA, J. Glaciol., 49, 370-380, 2003.

Sturm, M., Holmgren, J., König, M., and Morris, K.: The thermal conductivity of seasonal snow, J. Glaciol., 43, 26-41, 1997.

Sou, T. and Flato, G.: Sea Ice in the Canadian Arctic Archipelago: Modeling the Past (1950-2004) and the Future (2041-60), J. Climate., 22, 2181-2198, 2009.

Thorne, R.: Uncertainty in the impacts of projected climate change on the hydrology of a subarctic environment: Liard River Basin, Hydrol. Earth Syst. Sci., 15, 1483-1492, doi:10.5194/hess-151483-2011, 2011.

Tomkins, J. D., Lamoureux, S. F., Antoniades, D., and Vincent, W. F.: Sedimentary pellets as an ice-cover proxy in a High Arctic ice-covered lake, J. Paleolimnol., 41, 225-242, 2009.

Vavrus, S. J., Wynne, R. H., and Foley, J. A.: Measuring the sensitivity of southern Wisconsin lake ice to climate variations and lake depth using a numerical model, Limnol. Oceanogr., 41, 822831, 1996.

Verseghy, D. L.: CLASS - A Canadian land surface scheme for GCMs. Part I: Soil model, Int. J. Climatol., 11, 111-133, 1991.

Verseghy, D. L., McFarlane, N. A., and Lazare, M. CLASS - A Canadian land surface scheme for GCMs. Part II: Vegetation model and coupled runs, Int. J. Climatol., 13, 347-370, 1993.

Vincent, L. A.: A technique for the identification of inhomogeneities in Canadian temperature series, J. Climate, 11, 10941104, 1998.

Vincent, L. A. and Gullet, D. W.: Canadian historical and 
homogeneous temperature datasets for climate change analyses, Int. J. Climatol., 19, 1375-1388, 1999.

Vincent, L. A., Zhang, X., Bonsal, B. R., and Hogg, W. D.: Homogenization of daily temperatures over Canada, J. Climate, 15, 1322-1334, 2002.

Walsh, S. E., Vavrus, S. J., Foley, J. A., Fisher, V. A., Wynne, R. H., and Lenters, J. D.: Global pattern of lake ice phenology and climate: Model simulation and observations, J. Geophys. Res., 103, 28825-28837, 1998.

Weyhenmeyer, G. A., Meili, M., and Livingstone, D. M.: Nonlinear temperature response of lake ice breakup, Geophys. Res. Lett., 31, L07203, doi:10.1029/2004GL019530, 2004.
Williams, G., Layman, K. L., and Stefan, H. G.: Dependence of lake ice covers on climatic, geographic and bathymetric variables, Cold Reg. Sci. Technol., 40, 145-164, 2004.

Woo, M. K., Thorne, R., Szeto, K., and Yang, D.: Streamflow hydrology in the boreal region under the influences of climate and human interference, Phil. Trans. R. Soc. B, 363, 2251-2260, doi:10.1098/rstb.2007.2197, 2008.

Zhang, X., Zwiers, F. W., Hegerl, G. C., Lambert, F. H., Gillett, N. P., Solomon, S., Stott, P. A., and Nozawa, T.: Detection of human influence on twentieth-century precipitation trends, Nature, 448, 461-466, doi:10.1038/nature06025, 2007. 